\title{
Extradition of Government Agents as a Municipal Law Remedy for State- Sponsored Kidnapping
}

\author{
Jeffrey J. Carlisle $\uparrow$
}

The United States has repeatedly asserted the right to effect arrests abroad. The Supreme Court has recently reaffirmed that U.S. courts can exercise personal jurisdiction over a defendant brought before it, irrespective of whether the arrest violated international law. In this Comment, the author notes that cross-border abductions by agents of the United States government violate not only international law, but also the foreign state's municipal law. Such a violation gives rise to the possibility that the foreign country could request extradition of the government agents to face trial. In such a case, the author argues that U.S. federal courts should warrant the extradition of U.S. government agents who have entered foreign territory to perpetrate cross-border abductions. For a court deciding whether to warrant extradition, government agents ought to be treated the same as private actors. They would not be the beneficiaries of sovereign immunity. Nor would a court's warrant of extradition constitute an impermissible interference into the foreign policy powers of the Executive, since the U.S. extradition statute provides that the Secretary of State retains the discretion to order extradition.

\section{INTRODUCTION}

[Abduction] is a far less aggressive action-and far less intrusive on the sovereignty of another nation-than retaliatory bombing raids.

Senator Arlen Specter ${ }^{1}$

Sweeping assertions of the right of the United States government to effect arrests abroad stem in large part from a reading of a century-old

Copyright $\odot 1993$ California Law Review, Inc.

$\dagger$ B.A. 1990, University of California, Los Angeles; J.D. candidate 1994, Boalt Hall School of Law, University of California, Berkeley; M.A.L.D. candidate 1994, The Fletcher School of Law and Diplomacy, Tufts University. The author wishes to express his thanks to Professor Alfred P. Rubin of the Fletcher School for his advice, which was alvays helpful even though it occasionally turned up in the most unexpected places. See Alfred P. Rubin, Book Review, 17 Fletcher F. WORLD AFF. 226, 228 (1993).

1. Arlen Specter, How to Make Terrorists Think Twice, N.Y. Times, May 22, 1986, at A31. 
case, Ker v. Illinois. ${ }^{2} \mathrm{Ker}$ held that even though a defendant was kidnapped in Peru and brought to the United States by a private citizen to face trial, he could not challenge personal jurisdiction of the court under due process or under the applicable extradition treaty. In doing so, the Court entrenched the principle of male captus, bene detentus ("a person improperly seized may nevertheless properly be detained (and brought to trial)"3) in American law. The continuing influence of Ker and Frishie v. Collins, ${ }^{4}$ a later case which reaffirmed $\mathrm{Ker}$ in the context of an abduction between states of the Union, was recently demonstrated by the Supreme Court in United States v. Alvarez-Machain. ${ }^{5}$ In Alvarez-Machain, the Court upheld the assertion of personal jurisdiction over a Mexican citizen who was kidnapped from Mexico to stand trial for the 1985 murder of DEA agent Enrique Camarena-Salazar. Both before and after the Court's ruling in Alvarez-Machain, legal journals were inundated by a torrent of ink either questioning or championing the application of the Ker-Frisbie Doctrine in Alvarez-Machain, ${ }^{6}$ where the abduction was carried out by agents of the U.S. government without the consent of the Mexican government.

Despite the voluminous amount of legal scholarship opposing the application of the Ker-Frisbie Doctrine, the Court's ruling in AlvarezMachain ensures that Ker-Frisbie will remain the law for the foreseeable future. Although further direct attacks on the Ker-Frisbie Doctrine thus

2. 119 U.S. 436 (1886). Almost entirely on the basis of Ker, Senator Specter stated that abduction "is entirely legal and appropriate, in accordance with international rules of law and with United States law." Bills to Authorize Prosecution of Terrorists and Others Who Attack U.S. Government Employees and Citizens Abroad: Hearing on S. 1373, S. 1429, \& S. 1508 Before the Subcomm. on Security and Terrorism of the Senate Comm. on the Judiciary, 99th Cong., 1st Sess. 40 (1985) [hereinafter Hearing] (statement of Sen. Arlen Specter).

3. Louis Henkin, International Law: Politics, Values and Functions, 216 RECUEIL DES COURS 11,305 (1990).

4. 342 U.S. 519 (1952).

5. 112 S. Ct. 2188 (1992).

6. For analyses before Alvarez-Machain, see generally Jonathan Gentin, GovernmentSponsored Abduction of Foreign Criminals Abroad: Reflections on United States v. Caro.Quintero and the Inadequacy of the Ker-Frisbic Doctrine, 40 EMORY L.J. 1227 (1991) (arguing that the cases presented an opportunity to overturn Ker-Frisbie); Andreas F. Lowenfeld, Kidnaping by Government Order: $A$ Follow-Up, 84 AM. J. INT'L L. 712 (1990) [hereinafter Lowenfeld, Kidnaping by Government Order] (discussing facts of Alvarez-Machain in context of argument against governmentsponsored abductions); Andreas F. Lowenfeld, Still More on Kidnaping, 85 AM. J. INT'L L. 655 (1991) [hereinafter Lowenfeld, Still More on Kidnaping] (generally approving of circuit court decisions to release defendants in Alvarez-Machain and Verdugo-Urquidez); Mitchell J. Matorin, Unchaining the Law: The Legality of Extraterritorial Abduction in Lieu of Extradition, 41 DUKE L.J. 907 (1992) (arguing that courts should not intervene where executive concludes abduction is warranted). For analyses since Alvarez-Machain, see generally Michael J. Glennon, State-Sponsored Abduction: A Comment on United States v. Alvarez-Machain, 86 AM. J. INT'L L. 746 (1992) (arguing that Alvarez-Machain short-sightedly ignores national interests in respecting international law); Malvina Halberstam, In Defense of the Supreme Court Decision in Alvarez-Machain, 86 AM. J. INT'L L. 736 (1992) (arguing that Alvarez-Machain was consistent with international law and executive's power over foreign affairs). 
are not likely to produce a marked change in U.S. law, other consequences of cross-border abduction, aside from personal jurisdiction over the kidnapped person, have yet to be fully discussed or resolved. Abduction undoubtedly has other consequences in international law and-despite the foreclosing of challenges to personal jurisdiction-continues to have consequences in municipal law.

One of these consequences is that cross-border abductions carried out by government agents on the territory of another state constitute a violation of that state's municipal law, giving rise to the possibility that the foreign country could request extradition of the government agents to face trial. Under U.S. law, a federal court may, upon a request from a foreign government, warrant the extradition of an individual, with the Executive Branch then exercising its discretion to execute the warrant by ordering extradition. ${ }^{7}$ As was shown by the extradition of two U.S. bounty hunters for an abduction in Canada in Kear v. Hilton, ${ }^{8}$ private citizens may be extradited for cross-border abductions. Why not, then, allow the federal courts to treat government agents acting on a foreign state's territory without that state's consent similarly to private citizens, since the agents are not authorized by the local law of the state where the seizure occurs to carry out law enforcement activities? The answer to this question seems deceptively simple, although it raises, in turn, serious questions under both international and U.S. law: Would governinent agents carrying out law enforcement actions be the beneficiaries of sovereign immunity? Is extradition of government agents otherwise possible under the terms of extradition treaties? Would warranting the extradition of U.S. government agents to foreign countries constitute impermissible interference by federal courts with the foreign policy powers of the Executive Branch?

This Comment argues that U.S. federal courts should warrant the extradition of U.S. government agents who have entered foreign territory to perpetrate cross-border abductions. The extradition and prosecution of government agents for carrying out police functions in other countries is not only supported by municipal precedent but does not seem to raise the same questions of immunity under international law as would the prosecution of military or diplomatic personnel. The political question of interference with the Executive Branch is resolved by the fact that federal courts only warrant extradition to the Executive, which retains discretion to order it. Thus, warranting extradition of U.S. government agents allows federal courts to perform their legal duty, while placing the political questions involved in the extradition of government agents wholly in the hands of the Executive Branch.

7. See 18 U.S.C. \$3184 (Supp. IV 1992); see also infra notes 134-40, 226-33 and accompanying text.

8. 699 F.2d 181 (4th Cir. 1983). 
Part I clarifies the question of extradition of government agents by summarizing and briefly comparing the primary cases giving rise to the question. Part II determines the consequences of state-sponsored abductions within the international legal order, including the limited availability of immunity from municipal prosecution for government agents. Part III examines U.S. and foreign precedent indicating that government agent status does not constitute an exemption from extradition under U.S. municipal law, foreign municipal law, or relevant treaty law. Finally, Part IV sets forth the policy in favor of extraditing government agents and examines such extradition in light of the foreign policy power of the Executive and the doctrine of justiciability. The Comment concludes that courts warranting extradition are not intruding on the prerogative of the Executive in foreign relations, particularly since statutory law explicitly delegates political discretion to order extradition to the Executive.

\section{I}

KER-FRISBIE, KEAR V. HILTON, AND UNITED STATES $v$. ALVAREZ-MACHAIN

Discussion of the Ker-Frisbie Doctrine, and of cross-border abductions in general, usually focuses on the rights of the abducted person. As the focus of this Comment is on the abductors, a brief recounting of KerFrisbie and a comparison with Kear and Alvarez-Machain is necessary to draw the problem into sharper relief. This Comment will use the term "government agents" to refer to officials, employees, or other paid agents of national governments. Where necessary, officials, employees, or other paid agents of the United States will be distinguished as "U.S. government agents."

\section{A. Discussion of Cases}

\section{The Ker-Frisbie Doctrine $e^{10}$}

In Ker, Henry Julian, a Pinkerton detective, traveled to Peru with a request from the President of the United States for the extradition of

9. I recognize that in international law the term "government" is completely different from the term "state" and that, accordingly, "government agent" may connote a different meaning from "state agent," the term usually used in the literature. "Government agent" should be taken to mean no more or less than what the text sets forth, and was chosen primarily to avoid confusion between states in the international sense and states of the United States.

10. For cases applying the Doctrine, see Gerstein v. Pugh, 420 U.S. 103, 119 (1975); United States v. Yunis, 924 F.2d 1086, $1092-93$ (D.C. Cir. 1991); United States v. Lira, 515 F.2d 68, 70-71 (2d Cir.), cert. denied, 423 U.S. 847 (1975); United States v. Sobell, 142 F. Supp. 515, 523-25 (S.D.N.Y. 1956), aff'd, 244 F.2d 520 (2d Cir.), cert. denied, 355 U.S. 873 (1957); see also M. CherIF Bassiouni, International Extradition: United States Laiv and Practice 201.05 \& n.49 (2d rev. ed. 1987) (discussing the Doctrine); John G. Kester, Some Myths of United States Extradition Law, 76 GEo. L.J. 1441, 1449-55 (1988) (criticizing the Doctrine). 
Frederick Ker, but never delivered the request to the Peruvian government. ${ }^{11}$ Instead, according to the Supreme Court, he simply abducted Ker and brought him back to the United States to face embezzlement charges in an Illinois state court. ${ }^{12}$ The Court, reviewing Ker's conviction, not only held that the abduction did not violate due process under the Fourteenth Amendment, ${ }^{13}$ but also held that the abduction did not violate the extradition treaty with Peru since the abduction was "without any pretence of authority under the treaty or from the government of the United States."14 Moreover, the Court did not decide whether a lack of jurisdiction should be found under Illinois law because of the abduction, noting only that there was authority allowing such exercise. ${ }^{15}$ The Court explicitly distinguished Ker's failed challenge to jurisdiction from remedies against Julian, stating that the extradition treaty with Peru "provides for the extradition of persons charged with kidnapping, and on demand from Peru, Julian . . . could be surrendered and tried in its courts for this violation of its laws."16

In Frisbie, the defendant alleged that he was kidnapped in Chicago, Illinois by police officers from Michigan to face trial for murder in Michigan. ${ }^{17}$ The Sixth Circuit granted the defendant's petition for a writ of habeas corpus, holding that $\mathrm{Ker}$ could not apply because of the passage of the Federal Kidnapping Act in 1932. ${ }^{18}$ Whereas Ker did not involve conduct contrary to any statute or the Constitution, the Michigan police officers acted outside their territorial jurisdiction, without legal authority, and hence violated the Act, which applied to "[w] hoever unlawfully seizes, confines, inveigles, decoys, kidnaps, abducts, or carries away and holds for ransom or reward or otherwise any person ... when ... the person is willfully transported in interstate or foreign commerce." 19 Federal or state law enforcement officers were not explicitly exempted from this prohibition. Since the arrest was thus

11. Ker v. Illinois, 119 U.S. 436,438 (1886). For an explanation of why Julian chose not to seek extradition, see infra text accompanying notes 200-01.

12. Id. at 438 .

13. Id. at $439-40$ ("[F]or mere irregularities in the manner in which he may be brought into the custody of the law, we do not think he is entitled to say that he should not be tried at all ....").

14. Id. at 443. The Court also held that Ker's act of fleeing to Peru did not create a right of asylum, since Peru could have voluntarily surrendered him without extradition at any time. Id. at 442.

15. Id. at 444. The Court cited to, among other cases, The Ship Richmond v. United States, 13 U.S. ( 9 Cranch) 102 (1815), which held that the Court would not annul proceedings against a vessel because it was seized in foreign territory; the seizure was an offense against the foreign government and should be resolved politically.

16. Ker, 119 U.S. at 444 . The Court also pointed out that Ker could pursue a private action against Julian. Id.

17. Frisbie v. Collins, 342 U.S. 519,520 (1952).

18. Collins v. Frisbie, 189 F.2d 464 (6th Cir. 1951), rev'd, 342 U.S. 519 (1952).

19. 18 U.S.C. $\$ 1201(a)(1)$ (1988) (emphasis added). The current wording of the statute is unchanged from the version applied in Collins. 
illegal, the defendant was released. ${ }^{20}$ The Supreme Court reversed on the basis of $K e r,{ }^{21}$ but again emphasized the difference between jurisdiction over the kidnapped party and treatment of the kidnappers. The Court, without deciding the issue, assumed that the Michigan police officers violated the Federal Kidnapping Act, but refused to use this violation as a basis for denying jurisdiction since the Act did not include such a sanction. ${ }^{22}$

\section{Kear v. Hilton ${ }^{23}$}

Ker and Frisbie's neat distinction between jurisdiction over the abducted person and prosecution of the abductors was demonstrated by the proceedings following the abduction of Sidney Jaffe from Canada. ${ }^{24}$ On August 7, 1980, Jaffe was arrested in Putnam County, Florida and charged with twenty-eight counts of violating notification requirements of the Florida Land Sales Practices Act. ${ }^{25}$ After Accredited Surety \& Casualty Company (hereinafter "Accredited"), a Florida bonding company, posted Jaffe's $\$ 137,500$ bond, Jaffe went to Canada, where he acquired citizenship. ${ }^{26} \mathrm{Jaffe}$ did not return to face trial in the United States in May 1981, and the following November he was convicted in absentia of all twenty-eight violations of the Land Sales Practices Act and one count of failure to appear. ${ }^{27}$

After the State Attorney General denied two applications by Florida state attorneys for Jaffe's extradition, ${ }^{28}$ Accredited faced forfeiture of its

20. Collins, 189 F.2d at 468 ("[A] citizen . . . may not be seized, kidnaped and forcibly abducted from one state to another by police officers acting beyond their territorial jurisdiction in violation of a criminal law of the United States enacted to prevent kidnaping.").

21. Frisbie, 342 U.S. at 522-23.

22. Id.

23. 699 F.2d 181 (4th Cir. 1983).

24. The most complete summaries of the facts of the Jaffe case can be found in Jaffe v. Snow, 610 So. $2 d 482$ (Fla. Dist. Ct. App. 1992); Jaffe v. Boyles, 616 F. Supp. 1371, 1373-74 (W.D.N.Y. 1985); Jaffe v. Dearing, Nos. 5236/85, 10453/86, 1991 Ont. C.J. LEXIS 1602, at *1-*13 (Ont. Ct. J. Nov. 14, 1991) (Can.); Wade A. Buser, Note, The Jaffe Case and the Use of International Kidnapping as an Alternative to Extradition, $14 \mathrm{G}_{\mathrm{A}}$. J. INT'L \& COMP. L. 357, $373-75$ (1984).

25. Jaffe allegedly violated the Act when, after buying a subdivided lot, he offered quitclaim deeds to the purchasers of the lots rather than warranty deeds as promised by the original owner, thus violating Fla. STAT. ANN. § 498.033(3) (West 1979) (current version at Fla. Stat. ANN. $\S 498.033(2)$ (West 1993)), which required that he notify the state when making a modification to the original offering. Jaffe v. State, 438 So. $2 d$ 72, $73-74$ (Fla. Dist. Ct. App. 1983). Jaffe issued the quitclaim deeds because the holder of the mortgage on the lots refused to release them to the purchasers. Id. The purchasers thus received nothing for their payments to Jaffe, and suffered losses amounting to approximately $\$ 2.25$ million. See Kerry Gruson, Return of Land-Sales Figure for Florida Jailing is Assailed, N.Y. TIMES, Aug. 9, 1983, at A6 (reporting the dollar figure).

26. Kear, 699 F.2d at 181-82.

27. Jaffe v. State, 438 So. $2 d$ at 74.

28. The denials were apparently based on improper form. See Jaffe v. Smith, 825 F.2d 304 . 305 (11th Cir. 1987). Regardless, violations of Florida's Land Sales Act were not listed as onc of the extraditable offenses under the Treaty on Extradition Between the United States of America and Canada, Dec. 3, 1971, U.S.-Can., art. 2, annexed schedule II 1-30, 27 U.S.T. 985, 997-99. See Jaffe 
bond. It entered into an agreement with the Putnam County State Prosecutor's office and the county court pursuant to which the $\$ 137,500$ was placed in an escrow account and would be forfeited to the County if Jaffe were not produced within ninety days. ${ }^{29}$ Shortly after Accredited entered into the agreement, an Accredited employee, Daniel Kear, and a professional bounty hunter, Tinum Johnsen, went to Canada to abduct Jaffe. On September 23, 1981, Kear and Johnsen seized Jaffe as he returned to his apartment in Toronto after jogging. They handcuffed Jaffe, placed him in the back of a car, and drove to Niagara Falls, New York, where the party took a plane to Florida. ${ }^{30}$

In marked contrast to the relatively simple abduction, Jaffe, Kear, and Johnsen were each subjected to several years of criminal prosecution. A diplomatic incident erupted over Jaffe, who was sentenced to thirtyfive years in prison but was freed on parole in 1983 after his land sales fraud convictions were overturned on appeal. ${ }^{31}$ In July 1983, shortly before his release, the Florida State Attorney filed charges of organized fraud against him based on the same transactions which gave rise to the first charge. ${ }^{32}$ Not surprisingly, Jaffe returned to Canada and again refused to appear in court in Florida, stating, "I'm sitting here."33 $\mathrm{He}$ then proceeded to sue everyone even remotely connected with the incident. $^{34}$ Meanwhile, Canada sought the extradition of Kear and Johnsen

v. Snow, 610 So. $2 d$ at 484 n.2 (quoting from trial court opinion); Buser, supra note 24 , at 373 \& n. 128 (noting that the treaty mentions fraud, but not violations of Land Sales Practices Act). It is thus unlikely that Jaffe would have been extradited anyway.

29. Accredited Sur. \& Casualty Co. v. State, 418 So. 2d 378, 379 (Fla. Dist. Ct. App. 1982).

30. Jaffe v. Boyles, 616 F. Supp. 1371, 1373-74 (W.D.N.Y. 1985).

31. His sentence resulted from 28 five-year sentences for violations of the Land Sales Practices Act, seven imposed consecutively and the rest concurrently, as well as a concurrent five-year sentence for failure to appear. State ex rel. Boyles v. Florida Parole \& Probation Comm'n, 436 So. 2d 207, 209 (Fla. Dist. Ct. App. 1983). Canada demanded Jaffe's release, and unsuccessfully filed a habeas corpus petition in federal district court. Putnam County vs. Canada: Two U.S. Bounty Hunters Stir an International Legal Battle, TIME, Aug. 8, 1983, at 58, 58 [hereinafter Putnam County us. Canada]. Meanwhile, Secretary of State George Shultz wrote a letter to the Florida State Parole Board asking that, in light of the diplomatic incident, Jaffe be paroled early. Marian Nash Leich, Contemporary Practice of the United States Relating to International Law, 78 AM. J. INT'L L. 200, 207-08 (1984). Eventually, Jaffe's convictions for violating the Land Sales Practices Act were overturned on the bases that the trial judge misdirected the jury and that the prosecutors failed to file correct charging papers. Jaffe v. State, 438 So. $2 \mathrm{~d}$ at $75-76$. He was released on parole for the failure to appear count on October 11, 1983. Florida Parole Board Votes to Free Canadian, N.Y. TIMES, Oct. 6, 1983, at A18.

32. Canadian, Kidnapped to Stand Trial in Florida, Is Free on Bond, N.Y. Times, Oct. 12, 1983, at A14.

33. Canadian Refuses to Face Florida Trial, L.A. Times, Apr. 16, 1985, at 8.

34. Jaffe sued Accredited, its officers and attorney, the state prosecutor in Florida and several other government entities, and a single sheriff in Niagara Falls who failed to prevent Kear and Johnsen from taking him on the plane. Jaffe v. Boyles, 616 F. Supp. at 1371-74. Litigation regarding the incident continues to this very day. See Jaffe v. Miller, 75 O.R.2d 133 (Ont. High Ct. J. 1990) (Can.); Jaffe v. Miller, 3 O.R.3d 680 (Ont. Ct. Gen. Div. 1991) (Can.). In November 1992, a Florida court of appeals refused to enforce a Canadian judgment obtained by Jaffe's wife for mental and physical suffering and loss of consortium as a result of her husband's imprisonment. Jaffe $v$. 
for violating the Canadian statute against kidnapping. ${ }^{35}$ In Kear $v$. Hilton, the Fourth Circuit affirmed the lower court's denial of Kear's petition for a writ of habeas corpus and allowed his extradition to Canada to proceed. ${ }^{36}$ The court based its decision on Reese $v$. United States, ${ }^{37}$ where the Supreme Court held that the power of a bail surety cannot be exercised outside of the United States. ${ }^{38}$

Nevertheless, Kear argued that he could not be extradited to Canada since the Federal Kidnapping Act would not apply to a Canadian bounty hunter who captured a fugitive in the United States and that the treaty of extradition required crimes to be punishable by both countries. ${ }^{39}$ The court rejected this argument, holding that precedents of seizures within the United States for the return of fugitives to federal or state courts "are simply inapposite to a situation such as the one which confronts us, where considerations of sovereignty and the crossing of an international boundary intervene."40

In June 1985, Kear and Johnsen were found guilty of kidnapping in Canada and were sentenced to twenty-one months in prison by a trial judge who warned American bounty hunters to stay out of Canada. ${ }^{4 !}$ Kear and Johnsen appealed both their convictions and their sentences. In October 1989, the Court of Appeal for Ontario dismissed the appeal of their convictions since "they were without lawful authority when they seized Jaffe and took him out of Canada" but allowed the appeals of their sentences and reduced their sentences to time served. ${ }^{42}$ Although the court cited to the particular facts of the case arguing in favor of leniency, ${ }^{43}$ the court stated that "the very conviction of those men of one of the most serious offences known to Canadian law would go a long way towards the vindication of Canada's sovereignty and towards repudiation

Snow, 610 So. 2d 482, 483 (Fla. Dist. Ct. App. 1992), review denied, 621 So. 2d 432 (Fla. 1993). As this Comment went to print, the most recent activity in Mrs. Jaffe's case was an application for a writ of certiorari from the U.S. Supreme Court, over which the Court asked for the Clinton Administration's views on October 12, 1993. See Linda Greenhouse, Justices to Rule on Challenges by Career Criminals, N.Y. TIMES, Oct. 13, 1993, at A19.

35. Kear v. Hilton, 699 F.2d 181, 182-83 (4th Cir. 1983). Canada's kidnapping statute is in the Criminal Code, R.S.C. $\$ 247(1)$ (1970) (Can.). Subsection (b) concerns the removal of the kidnapped victim from Canada.

36. Kear, 699 F.2d at 185 . Johnsen was extradited in separate proceedings. See Leich, supra note 31, at 208 \& n.2 (citing In re Extradition of Johnsen, No. 82-48M-01 (M.D. Fla. 1982)).

37. 76 U.S. ( 9 Wall.) 13 (1869).

38. Kear, 699 F.2d at 182 (citing Reese, 76 U.S. at 21-22).

39. Id. at 183.

40. Id. 19.

41. Canada Sentences Two For Seizing Businessman, L.A. TIMES, June 11, 1986 (late ed.), at

42. The Queen v. Kear, No. 498/66, 1989 Ont. C.A. LEXIS 187, at *3, *5 (Ont. Ct. App. Oct. 18, 1989) (Can.).

43. The court pointed out, inter alia, that while Kear and Johnsen were "men of good character and repute," there was "nothing favourable that can be said about [Sidney Jaffe's] conduct." Id. at *4. 
of their affront to it."44

\section{United States v. Alvarez-Machain}

Whereas Ker and Kear involved abductors whom the courts considered private citizens, Alvarez-Machain involved U.S. government agents, and thus directly raises the question of whether such agents can be extradited. In February 1985, Enrique Camarena-Salazar, a Drug Enforcement Agency (DEA) agent who had been working undercover in Mexico, was kidnapped, tortured, and killed. A subsequent investigation under Special Agent Hector Berrellez resulted in the indictment of twenty-two people, including two Mexican citizens, René Martín Verdugo Urquídez and Dr. Humberto Alvarez Macháin. ${ }^{45}$ Verdugo Urquidez was arrested by Mexican law enforcement officers on January 24, 1986, and handed over to U.S. marshals at the Mexican-American border. ${ }^{46}$ While Verdugo Urquídez was being prosecuted for several other narcotics offenses, he was also charged with the murder of Camarena-Salazar, and was eventually sentenced to four consecutive sixty-year terms to run concurrently with a life sentence. ${ }^{47}$

After unsuccessful negotiations with Mexican federal police to obtain Dr. Alvarez Macháin, a gynecologist from Guadalajara, Berrellez received authorization from his immediate superiors in Los Angeles and from the Deputy Director of the DEA to arrange Alvarez Macháin's kidnapping. The arrangements were made through Antonio Gárate Bustamante, a DEA informant and former associate of Mexican drug lord Ernesto Fonseca Carrillo. ${ }^{48}$ On April 2, 1990, five or six armed Mexican citizens abducted Alvarez Macháin from his office. With the help of several other Mexican citizens, they took him by plane to El

44. Id. But see infra text accompanying notes 88-92 (noting that acts of private citizens cannot give rise to a violation of sovereignty).

45. United States v. Caro-Quintero, 745 F. Supp. 599, 601-02 (C.D. Cal. 1990), aff'd sub nom. United States v. Alvarez-Machain, 946 F.2d 1466 (9th Cir. 1991), rev'd, 112 S. Ct. 2188 (1992). For the prosecution of another indicted suspect, see Matta-Ballesteros ex rel. Stolar v. Henman, $697 \mathrm{~F}$. Supp. 1040 (S.D. Ill. 1988), aff'd, 896 F.2d 255 (7th Cir.), cert. denied, 498 U.S. 878 (1990); see also Andreas F. Lowenfeld, U.S. Law Enforcement Abroad: The Constitution and International Law, Continued, 84 AM. J. INT'L L. 444, 446-48 (1990) (discussing Matta-Ballesteros). Matta-Ballesteros differs from Alvarez-Machain in that the defendant's rendition involved the cooperation of the Honduran government. Matta-Ballesteros, 697 F. Supp. at 1041-42.

46. United States v. Verdugo-Urquidez, 856 F.2d 1214, 1215-17 (9th Cir. 1988), rev'd, 494 U.S. 259 (1990).

47. United States v. Verdugo-Urquidez, 939 F.2d 1341, 1343-44 (9th Cir. 1991), vacated, 112 S. Ct. 2986 (1992); see also Lowenfeld, Still More on Kidnaping, supra note 6, at 656-57 (discussing Verdugo Urquidez's abduction). During his prosecution for the narcotics offenses, Verdugo Urquidez appealed the admission of evidence obtained from his house in Mexico by Mexican officers and DEA agents, arguing that the search violated the exclusionary rule of the Fourth Amendment. While the Ninth Circuit held the evidence inadmissible, Verdugo-Urquidez, 856 F.2d at 1227-30, the Supreme Court reversed, holding that the Fourth Amendment does not apply to aliens outside the territory of the United States. United States v. Verdugo-Urquidez, 494 U.S. 259, 274-75 (1990).

48. Caro-Quintero, 745 F. Supp. at 601-03. 
Paso, Texas, where they delivered him to waiting DEA agents. ${ }^{49}$ The abductors received $\$ 20,000$, and seven of them were brought to the United States along with their families where they received expenses of $\$ 6000$ per week. ${ }^{50}$

The Mexican government sent a series of diplomatic notes to the State Department of the United States regarding the incident, and eventually requested the provisional arrest and extradition of Berrellez and Gárate Bustamante. ${ }^{51}$ Despite the rising diplomatic furor, the U.S. Attorney's Office proceeded with Alvarez Macháin's prosecution. In United States v. Caro-Quintero, the district court trying Alvarez Macháin held that the United States, by sponsoring his abduction from Mexico, violated its obligation to comply with the procedure under the extradition treaty between the United States and Mexico.52 The district court then ordered the government to return Alvarez Macháin. ${ }^{53}$ The government appealed the order.

One year later, the Ninth Circuit came to a similar conclusion as the district court in Caro-Quintero when it vacated the lower court's holding in Verdugo-Urquidez. ${ }^{54}$ Noting that there was some question as to whether the Mexican officers who abducted Verdugo-Urquidez were acting on their own authority or were hired by the DEA, the court remanded for an evidentiary hearing. The court held that U.S. sponsorship would constitute a violation of the extradition treaty and require the return of the defendant to Mexico. ${ }^{55} \mathrm{~A}$ few months later, the Ninth Circuit affirmed the lower court's holding in Caro-Quintero, citing to Verdugo-Urquidez. ${ }^{56}$

On the appeal of the Ninth Circuit's disposition of Alvarez Macháin's case, and after receiving amici curiae briefs from the

49. Id. at 603 .

50. See id. at 603-04; Lowenfeld, Kidnaping by Government Order, supra note 6, at 714. It is not clear how long the abductors received these weekly expenses.

51. United States v. Alvarez-Machain, 112 S. Ct. 2188, 2196 n.16 (1992); Caro-Quintero, 745 F. Supp. at 604; Brief for the United Mexican States as Amicus Curiae in Support of Affirmance at 3-4, United States v. Alvarez-Machain, 112 S. Ct. 2188 (1992) (No. 91-712); see also Diplomatic Note from the Embassy of Mexico to the State Department (Apr. 18, 1990) (requesting report on U.S. participation in the incident) (copy on file with author); Diplomatic Note from the Embassy of Mexico to the State Department (May 16, 1990) (protesting the abduction and demanding AlvarezMachain's release) (copy on file with author).

52. Caro-Quintero, 745 F. Supp. at 614; see also Extradition Treaty Between the United States of America and the United Mexican States, May 4, 1978, U.S.-Mex., 31 U.S.T. 5059.

53. Caro-Quintero, 745 F. Supp. at 614. A federal court reviewing Jaffe's abduction used exactly the same reasoning, stating that if Jaffe had been able to show state action, he would have been released since a treaty obligation of the United States would have been involved and Ker would not have applied. Jaffe v. Smith, 825 F.2d 304, 306-08 (11th Cir. 1987).

54. United States v. Verdugo-Urquidez, 939 F.2d 1341, 1343 (9th Cir. 1991), vacaled. 112 S. Ct. 2986 (1992).

55. Id. at $1343,1360$.

56. United States v. Alvarez-Machain, 946 F.2d 1466 (9th Cir. 1991) (per curiam), aff'g United States v. Caro-Quintero, 745 F. Supp. 599 (C.D. Cal. 1990), rev'd, 112 S. Ct. 2188 (1992). 
Governments of Mexico and Canada, ${ }^{57}$ the Supreme Court rejected the lower courts' opinions that the extradition treaty applied. ${ }^{58}$ The Court held, first, that the treaty did not explicitly prohibit abductions or otherwise provide that extradition was an exclusive process and, second, that no grounds for implying such a term into the treaty could be found. ${ }^{59}$ As such, the Court held that Ker-read here as allowing a court to exercise personal jurisdiction in cases of forcible abductions which are not violative of treaties-allowed the lower court to exercise jurisdiction, regardless of whether or not the abduction was carried out by government agents. ${ }^{60}$

While conceding that the abduction "may be in violation of general international law principles" and that the Mexican government had requested the extradition of Berrellez and Gárate Bustamante, the Court left further action on the case to the Executive Branch. ${ }^{61}$ One week later, the Court vacated the Ninth Circuit's remand in Verdugo-Urquidez on the authority of Alvarez-Machain. ${ }^{62}$ In December 1992, Alvarez Macháin was released after the federal district court judge trying him ordered the prosecution's case dismissed for lack of evidence. ${ }^{63}$

\section{B. Comparison of the Cases and Definition of the Problem}

The cases discussed above show that the following situations can arise in instances of cross-border abductions with consequences in U.S. law as follows:

(i) If private citizens (including bondsmen and bounty hunters) abduct a person in another country, courts may exercise personal jurisdic-

57. See Brief of the Government of Canada as Amicus Curiae in Support of Respondent, United States v. Alvarez-Machain, 112 S. Ct. 2188 (1992) (No. 91-712); Brief for the United Mexican States, supra note 51.

58. United States v. Alvarez-Machain, 112 S. Ct. 2188, 2193 (1992).

59. Id. at 2194-96. The Court barely distinguished United States v. Rauscher, 119 U.S. 407, 419-21 (1886), decided the same day as Ker, holding that the doctrine of specialty (maintaining that an extradited person can only be tried on a charge for which she was extradited) was an implied, although not expressly mentioned, part of an extradition treaty. The Court stated that implying a prohibition on abductions "requires a much larger inferential leap, with only the most general of international law principles to support it." Alvarez-Machain, 112 S. Ct. at 2196.

60. Alvarez-Machain, $112 \mathrm{~S}$. Ct. at 2193 ("If we conclude that the Treaty does not prohibit respondent's abduction, the rule in Ker applies, and the court need not inquire as to how respondent came before it."). For other cases mentioning the rule that prosecution may not proceed in the face of a violation of a treaty obligation, see Cook v. United States, 288 U.S. 102, 121 (1933) (holding that Ker-like rule regarding seized property does not apply where U.S. government restricted its jurisdiction by treaty); Ford v. United States, 273 U.S. 593, 605-06 (1927) (Taft, C.J.) (distinguishing $\mathrm{Ker}$ in dictum in situations where treaty applies).

61. Alvarez-Machain, 112 S. Ct. at $2196 \&$ n. 16.

62. United States v. Verdugo-Urquidez, 112 S. Ct. 2986 (1992) (mem.).

63. Jim Newton, Judge Orders Camarena Case Defendant Freed, L.A. Times, Dec. 15, 1992, at Al. After the court dismissed the government's case, U.S. attorneys unsuccessfully sought an emergency stay of the ruling, arguing that the defendant could not be set free because he was in the country illegally. Id. at A3. 
tion over the abducted person, and the abductors can be extradited to the other country to face charges of kidnapping. This outcome was indicated by Ker and follows directly from Kear v. Hilton.

(ii) If U.S. government agents abduct a defendant in another country, courts may exercise personal jurisdiction over the abducted person, but it is not clear whether the abductors may be extradited to the other country to face charges of kidnapping. Frisbie assumed, without deciding, that the Federal Kidnapping Act made abduction without authority illegal, but in that case the federal government did not prosecute the Illinois officers. Alvarez-Machain did not discuss the question, but noted the Mexican government's request.

For cases coming under (i), the law on the extradition of private citizens, bail bondsmen, and bounty hunters for cross-border abductions is straightforward. As Ker indicated, private citizens may be extradited to foreign countries to face charges of kidnapping. In Villareal $v$. Hammond, ${ }^{64}$ private citizens who abducted a fugitive in Mexico and brought him to the United States to receive a reward were extradited to Mexico to face charges of kidnapping, ${ }^{65}$ even though the fugitive was held for trial. ${ }^{66} \mathrm{~A}$ similar situation was resolved in the same way thirty years earlier when the United States agreed to extradite a private citizen who had kidnapped a Mexican citizen from Mexico, even though the abducted person was held for trial on the basis of Ker. ${ }^{67}$

Legally, bail bondsmen and bounty hunters who engage in crossborder abductions are treated like private citizens. The authority of bail bondsmen to recover bail jumpers is limited to United States territory. As was stated by the Supreme Court in Taylor v. Taintor, "[w] wen bail is given, the principal is regarded as delivered to the custody of his sureties,"68 who, through their own bail bondsmen or other agents, such as bounty hunters, have the power to seize the defendant anywhere in the

64. 74 F.2d 503 (5th Cir. 1934)

65. Id. at 505-06.

66. See Ex parte Lopez, 6 F. Supp. 342, 344 (S.D. Tex. 1934) (relying on Ker). The court in United States v. Caro-Quintero stated that Lopez was wrongly decided to the extent that it held that "unilateral forcible abduction may not violate an extradition treaty." $745 \mathrm{~F}$. Supp. 599,611 n. 18 (C.D. Cal. 1990), aff'd sub nom. United States v. Alvarez-Machain, 946 F.2d 1466 (9th Cir. 1991), rev'd, 112 S. Ct. 2188 (1992).

67. Papers Relating to the Foreign Relations of the United States, H.R. Doc. No. 1, 59th Cong., 2d Sess., pt. 2, at 1121-22 (1906); see also 3 MaUrice Travers, Le Droit Pénal international et Sa Mise en Oeuvre en Temps de Paix et en Temps de Guerre $\S 1303$ (1924).

68. 83 U.S. ( 16 Wall.) 366,371 (1873). As was the case in Green v. State, 829 S.W.2d 222, 223 (Tex. Crim. App. 1992), the powers of bail sureties outlined in Taylor may be superseded by statc statutes abrogating the common law. This does not, however, vitiate the authority of Taylor on the general common law of bail securities. See, e.g., Lopez v. McCotter, 875 F.2d 273, $277-78$ (10th Cir.) (holding that in New Mexico, New Mexico's interpretation of the Uniform Criminal Extradition Act supersedes the common law of bail bondsmen as established in Taylor), cert. denied, 493 U.S. 996 (1989). 
United States and deliver her for trial without recourse to state officials for arrest or extradition. ${ }^{69}$ These powers, however, do not extend beyond the territorial boundaries of the United States. As the Supreme Court stated in Reese v. United States, "This power of arrest can only be exercised within the territory of the United States . . .."70

Kear provides the model case of the consequences of Reese's territorial limitation: an attempt by bondsmen to seize a bail jumper in another country may violate the law of the foreign country, and, if so, could subject the bondsmen to extradition. Kear never mentioned Ker, but the two cases are surprisingly similar in this respect since both cases admitted that the abductors were extraditable. ${ }^{71}$ In diplomatic exchanges with Canada following Jaffe's abduction and with Mexico following the Alvarez-Machain decision, the United States recognized the rule of this line of precedent, stating that extradition of bondsmen and bounty hunters was necessary to redress breaches of local law. ${ }^{72}$

Thus, the fact that $\mathrm{Ker}$ allows the prosecution of an abducted person does not imply in any way that the abductors are immune from prosecution for any violations of municipal law their actions may have caused. The Supreme Court thus used only half of the rule from Ker in AlvarezMachain; it only held that jurisdiction could be exercised over the abducted person. The legal consequences for the government agents as abductors have yet to be determined. Resolving the status of government agents under extradition treaties is made particularly difficult given that Ker, Kear, and even Alvarez-Machain indicate that there may be practical problems in distinguishing between private citizens and government agents. ${ }^{73}$ What, then, is the international and U.S. law regarding extradition of government agents for performing abductions in nonconsenting foreign countries?

69. Taylor, 83 U.S. (16 Wall.) at 371.

70. 76 U.S. (9 Wall.) 13, 21 (1869).

71. Ker v. Illinois, 119 U.S. 436, 444 (1886); Kear v. Hilton, 699 F.2d 181, 183 (4th Cir. 1983); see also Lowenfeld, supra note 45 , at 464 \& n.98 (noting the similarity between Ker and Kear).

72. See Letter from George P. Shultz, Secretary of State, to Joe Clark, Secretary of State for External Affairs of Canada (Jan. 11, 1988), in Brief of the Government of Canada, supra note 57, app. B at 4a ("The United States and Canada recognize that the transborder abduction of person [sic] ... by civilian agents of bail bonding companies ... is an extraditable offense under the United States-Canada Extradition Treaty."); Alan J. Kreczko, Prepared Statement on the Supreme Court's Decision in United States v. Alvarez-Machain Before the Civil and Constitutional Rights Subcomm. of the House Comm. on the Judiciary 13-14 (July 24, 1992) (unpublished manuscript, on file with author) (discussing exchange of letters between Secretary of State James A. Baker III and Foreign Secretary Solana of Mexico "recognizing that transborder abductions by so-called "bounty hunters' and other private individuals will be considered extraditable offenses by both nations").

73. See infra text accompanying notes 198-203. 
II

\section{AbDuction by Government Agents UNDER INTERNATIONAL LAW}

\section{A. Male Captus, Bene Detentus in International Law}

The United States is not alone in refusing to question circumstances of rendition. ${ }^{74}$ Courts in Great Britain have upheld jurisdiction over defendants who had been kidnapped in another country even when British police officers were directly involved. ${ }^{75}$ In the famous trials of Adolf Eichmann, who was abducted from Argentina by Israeli agents, and Antoine Argoud, who was abducted from West Germany to France by abductors suspected of having connections to the French security services, the courts upheld jurisdiction in spite of the abductions. ${ }^{76}$ In the Argoud case, the French trial court held that a cross-border abduction, "although it engages the responsibility-even the criminal responsibility - of those who have committed it, is not of such a character as of itself to involve the nullity of the prosecution."77

However, the assertion of jurisdiction despite irregularities in rendition is essentially a municipal law question. ${ }^{78}$ Assertions of jurisdiction by municipal law tribunals do not mean that a transborder abduction by government agents does not violate public international law. As one author stated, "[s]urely male captus, bene detentus is not one of the principles that expresses the aspirations of international law, or that inspires

74. See I.A. SHEARER, ExTRADITION IN INTERNATIONAL LAW 72-74 (1971); Trial of Accused, 6 Whiteman DigesT $\S 46$, at 1108; Halberstam, supra note 6, at 737; F.A. Mann, Reflections on the Prosecution of Persons Abducted in Breach of International Law, in InTernational Law at a Time of Perplexity: Essays in Honour of Shabtai RosenNe 407, 412-14 (Yoram Dinstein ed., 1989).

75. For police officers, see Ex parte Elliott, 1 All E.R. 373 (K.B. 1949); Ex parte Scott, 109 Eng. Rep. 166, 167 (K.B. 1829). For abduction by a private party, see Extradition: Rendition of Fugitive Offenders, 6 Parry BRIT. DIG. INT'L L. $\S 8$, at $482-83$ (1965), which describes a case where the Law Officers believed that the only domestic remedy for a British citizen kidnapped by a creditor's agent in the United States was an action for assault and indictment of abductors, but that the defendant's release was preferable as a matter of policy.

76. For Eichmann, see Attorney-General of Israel v. Eichmann, 36 I.L.R. 18, 78-79 (Dist. Ct. Jerusalem 1961), aff'd, 36 I.L.R. 277 (Sup. Ct. Isr. 1962); see also Trial of Accused, supra note 74, at 1108-11 (summarizing the holdings of the District Court and the Supreme Court of Israel); L.C. Green, The Eichmann Case, 23 MoD. L. REv. 507, 515 (1960) (arguing that Israel might have to pay reparations, but would not have to return Eichmann). For Argoud, see Re Argoud, Cass. crim., 1964 Bull. Crim. No. 420 (Fr.), translated in 45 I.L.R. 90, 98; see also Bartholomé de Schutter, Competence of the National Judiciary Power in Case the Accused Has Been Unlawfully Brought Within the National Frontiers, 1 Revue Belge DE DRoIT INTERNATIONAL 88 (1965) (describing Argoud's case and briefly comparing it to Eichmann's); Henry Giniger, Argoud Convicted and Sentenced to Life Term, N.Y. TIMES, Dec. 31, 1963, at 3.

77. 45 I.L.R. at 97. But see In re Jolis, 1933-1934 ANN. DIG. \& REP. OF PUB. INT'L L. CASES 191 (releasing Belgian citizen arrested by French policeman in Belgium because arrest on forcign territory has no legal effect); 3 TRAVERS, supra note $67, \S 1302$ (I1) (detailing cases of Jérôme, Nollet, Jabouille, and P., who were all released following extraterritorial arrests).

78. See SHEARER, supra note 74 , at 73 . 
adherence to that law."79 Even the Court in Alvarez-Machain acknowledged that cross-border abductions "Inay be in violation of general international law principles." 80

This statement rather understates the fact of the matter. Crossborder abductions are violations of international law because one state's exercise of authority on another state's territory is a violation of the sovereignty of the latter. It is a long-standing principle of international law that a state's sovereignty within its own territory is supreme, necessarily admitting no other sovereigns. ${ }^{81}$ In 1927 , in the Lotus case, the Permanent Court of International Justice stated that "the first and foreinost restriction inposed by international law upon a State is that-failing the existence of a permissive rule to the contrary-it may not exercise its power in any form in the territory of another State." 82 The idea of territorial sovereignty was also endorsed by the U.S. Supreme Court in The Schooner Exchange v. M'Faddon, ${ }^{83}$ where Chief Justice Marshall stated that a nation's sovereign power, including its power to adjudicate the rights of foreign citizens and the ownership of foreign property, is absolute, adinitting only those exceptions which can be "traced up to the consent of the nation itself." 84

The Schooner Exchange goes on to hold that this consent may be express or implied. Express consent exceptions include those undertaken by treaty or other agreement between states, such as when military forces are in another country by agreement. Implied exceptions proceed from adherence to customary international law, with Marshall mentioning exceptions from local jurisdiction for heads of state, diplomats, military forces present with or without consent, and public ships. ${ }^{85}$

Accordingly, a violation of sovereignty would occur if the govern-

79. Lowenfeld, supra note 45 , at 477 .

80. United States v. Alvarez-Machain, 112 S. Ct. 2188, 2196 (1992).

81. Modern concepts of the independence of sovereign states can be traced as far back as the seventeenth century. See 1 Hugo Grotius, DE JuRE Belli ET PACIS ch. III, § VII, at 112 (William Whewell trans., Cambridge, Univ. Press 1853) (1625) ("That Power is called Sovereign, whose acts are not subject to the control of another, so that they can be rendered void by the act of any other human will."); see also 1 E. DE VATTEL, LE DroIt DEs GENS \$§ 15-20 (Charles G. Fenwick trans., Carnegie Inst. 1916) (1758) (setting forth independence and equality of nations as part of the foundation of the law of nations). See generally F.H. HinSLEY, SoverEIGNTY (1986) (tracing concepts of sovereignty to the ancient world and detailing development of the modern concepts).

82. The Case of the S.S. "Lotus" (Fr. v. Turk.), 1927 P.C.I.J. (ser. A) No. 9, at 18 (Sept. 7). The Lotus case did admit the possibility, however, that a state could exercise prescriptive jurisdiction, i.e., the jurisdiction to make conduct illegal, outside of its territory. $I d$. at 20; see also 1 ROBERT JENNINGS \& ARTHUR WATTS, OPPENHEIM'S INTERNATIONAL LAW pt. $1, \S 140$ (9th ed. 1992) [hereinafter OPPENHEIM].

83. 11 U.S. (7 Cranch) 116 (1812).

84. 11 U.S. (7 Cranch) at 135; see also Craig A. Morgan, Legitimate Responses to Aerial Intrusion in Time of Peace, 78 AM. Soc. INT'L L. Proc. 15, 27 (1984) (mentioning The Schooner Exchange as an exposition of international law).

85. 11 U.S. (7 Cranch) at 137-46. See generally OPPENHEIM, supra note 82, pt. 1, § 121 . 
ment agents of one state exercised their police power, including their power to make arrests, on the territory of another state without the second state's express or implied consent. ${ }^{86}$ If a violation of sovereignty does occur, it must be determined whether a violation could have been legally justified, for example as a measure of self-help as in cases of selfdefense. $^{87}$ Assuming that an abduction cannot be justified as a self-help measure, a nonconsensual abduction carried out by government agents would constitute a violation of sovereignty, and hence of international law.

\section{B. State Responsibility and Remedies for Violations of International Law by Government Agents}

Responsibility for violations of international law is imputed to the sponsoring state. ${ }^{88}$ Such vicarious liability in this context has two immediate implications. First, actions by private individuals in a foreign country which are not on behalf of a state do not involve a foreign sovereign's exercise of authority. Accordingly, cross-border abductions by private citizens do not give rise to a violation of international law since "[i]nternational responsibility is incurred only through official complicity." 89 As such, it is worth mentioning that the wording regarding

86. See SHEARER, supra note 74 , at 72 ("Where an abduction is effectively carried out, an infraction of the territorial sovereignty of the host State has been committed."). The Harvard Advisory Committee of the Research in International Law sought to prohibit just such a violation of sovereignty in Article 16 of its Draft Convention on Jurisdiction with Respect to Crime:

In exercising jurisdiction under this Convention, no State shall prosecute or punish any person who has been brought within its territory or a place subject to its authority by recourse to measures in violation of international law or international convention without first obtaining the consent of the State or States whose rights have been violated by such measures.

29 AM. J. INT'L L. 435, 623 (Supp. 1935). This is also reflected in the Restatement of Foreign Relations Law, which allows tbe exercise of police powers only with the consent of the foreign country. RESTATEMENT (THIRD) OF FOREIGN RELATIONS LAW OF THE UNITED STATES $\S \S 432$ (2) \& cmt. c, 433(1) (1987).

87. E.g., Destruction of the "Caroline," 2 Moore DIGEST $\$ 217$, at $409-14$ (presenting paradigmatic case of self-defense); see also Jeffrey A. Sheehan, The Entebbe Raid: The Principle of Self-Help in International Law as Justification for State Use of Armed Force, 1 FLETCHER F. WORLD AFF. 135, 136 (1977) (suggesting three forms of self-help: self-defense, reprisal, and retaliation). Care should be taken, however, to avoid stretching self-help arguments to the point where they become essentially meaningless, as was done by the United States to justify its surveillancc overflights of the Soviet Union after Francis Gary Powers was shot down in 1961. See Quincy Wright, Legal Aspects of the U-2 Incident, 54 AM. J. INT'L L. 836, 847-49 (1960).

88. See OPPENHEIM, supra note 82 , pt. 1, § 165; de Schutter, supra note 76, at 98-99; Michael Pugb, Legal Aspects of the Rainbow Warrior Affair, 36 INT'L \& CoMP. L.Q. 655, 660 (1987) ("It is also an established principle that a State which sends agents to commit an acta jure imperii abroad is liable rather than the agents wbo should enjoy immunity from local courts."); see, e.g., Colunje (Panama) v. United States, 6 R.I.A.A. 342, 344 (1933) ("For this act of a police agent in the performance of his functions, the United States of America should be held liable.").

89. Lawrence Preuss, Kidnaping of Fugitives from Justice on Foreign Territory, 29 AM. J. INT'L L. 502, 507 (1935); see also BASSIOUNI, supra note 10, at 194 (defining unlawful international abduction as one performed by "public agents or other persons acting under color of law"); 
Canda's sovereignty ${ }^{90}$ in Kear and in the Canadian courts hearing Kear and Johnsen's case was not, strictly speaking, accurate since Kear and Johnsen were not government agents. ${ }^{91}$ Second, since the responsibility for the violation of sovereignty is shifted to the state to resolve within the sphere of foreign relations, the individual actors cannot be held responsible for the violation in local courts..$^{92}$

Diplomatic resolution of such a violation of sovereignty can lead to several different types of remedy. The offending state will, at the very least, be obligated to offer apologies, or otherwise acknowledge that it has committed a breach of international law. ${ }^{93}$ Beyond apologies, reparations to the offended state inay be considered a suitable form of compensation..$^{94}$ Return of the kidnapped person to the offended state is also a widely recognized remedy for the violation of the offended state's sovereignty. ${ }^{95}$ For example, in the 1935 Jacob-Salomar case, where German agents kidnapped an expatriate from Switzerland, the German government returned the abducted person after the case had been submitted to arbitration. ${ }^{96}$ Thus, return of a kidnapped person through diplomatic

OPPENHEIM, supra note 82 , pt. $1, \S 165$ (defining state responsibility for acts committed by persons during course of official duties but without authorization); Green, supra note 76, at 515 (maintaining that there is no international responsibility for abductions by private individuals). Actions of private citizens can give rise to state responsibility if the private citizen acted on behalf of a state or if the state failed to exercise due diligence by protecting foreign property or citizens. OPPENHE1M, supra note 82 , pt. $1, \S 166$.

90. See supra notes 40,44 and accompanying text.

91. Those rhetorical flourishes, however, do not impair the value of the cases as precedent, however, since Kear and Johnsen's extradition and prosecution proceeded from the violation of Canadian municipal law rather than Canada's sovereignty.

92. Both the district court and the Supreme Court of Israel in Eichmann raised the issue of diplomatic settlement. Attorney-General of Israel v. Eichmann, 36 I.L.R. 18, 70 (Dist. Ct. Jerusalem 1961), aff'd, 36 I.L.R. 277 (Sup. Ct. Isr. 1962); Attorney-General of Israel v. Eichmann, 36 I.L.R. 277, 305 (Sup. Ct. Isr. 1962).

93. Eichmann's abduction was resolved by such acknowledgment. See Eichmann, 36 I.L.R. at 58-59; SHEARER, supra note 74, at 73. Argoud's abduction was also resolved by diplomatic settlement. See id. When a U.S. citizen was arrested in Canada by a U.S. customs official, diplomatic apologies were offered since the customs official believed he was in the United States, and hence, there was no intention to violate the sovereignty of the offended state. Breaches by Civil Authorities, 2 Moore Digest $\S 211$, at 381-82.

94. E.g., Colunje, 6 R.I.A.A. at $343-44$ (ordering compensation of $\$ 500$ for cross-border abduction).

95. See 1 Hersch LAUTERPACHT, OpPENHEIM's INTERNATIONAL LAW $§ 128$, at 295 n.1 (8th ed. 1955); Paul O'Higgins, Unlawful Seizure and Irregular Extradition, 1960 BRIT. Y.B. INT'L L. $279,293$.

96. See Lawrence Preuss, Settlement of the Jacob Kidnaping Case (Switzerland-Germany), 30 AM. J. INT'L L. 123, 123-24 (1936); see also Breaches by Civil Authorities, 2 Moore DigesT § 211, at 371-73 (dismissing charge of assault arising from a prisoner's escape when the United States protested his re-capture on U.S territory); Trent Case, 7 Moore DIGEST $\$ 1265$, at 768-70 (returning Mason and Slidell, diplomatic envoys from the Confederacy to Britain, who were seized at sea by a U.S. naval vessel); Extradition: Rendition of Fugitive Offenders, supra note 75 , at $482-83$ (returning British citizen seized in the United States by creditors' detectives after U.S. protest); Abducted Rhodesian Freed; Returns from South Africa, N.Y. TIMES, Sept. 3, 1964, at 6 (describing the return of Dennis Higgs, who was abducted from Rhodesia by South African agents, after protest). 
channels is possible even though local courts may refuse to do so under male captus, bene detentus. ${ }^{97}$ The Supreme Court in Alvarez-Machain suggested this possibility in mentioning that the Executive Branch should determine whether the defendant could be returned following diplomatic exchanges between Mexico and the United States. ${ }^{98}$

Punishment of government agents whose actions gave rise to the violation is another possible remedy. ${ }^{99}$ Although such action seems to contradict the vicarious responsibility of the sponsoring state for international delicts, the sponsoring state applies the punishment to its own agents, and the punishnient can thus be considered an internal disciplinary action. In the Jacob-Salomar case, the German governnient disciplined the agent found responsible. ${ }^{100}$ Similarly, the captain of a German gunboat in a Brazilian port was relieved of command after his crew broke into local houses while searching for a deserter. ${ }^{101}$ In 1920, U.S. government agents were punished after they invited a U.S. citizen on board a vessel at Bimini in the Bahamas and arrested him. ${ }^{102}$ Following a British protest of the action, the United States government reprimanded the agents, suspended them indefinitely, and exonerated the abducted person from all further proceedings. ${ }^{103}$

Regardless of what remedy is used to redress the violation of international law, the abducting government agents have also violated the municipal law of the foreign state where the kidnapping took place. Unless the abductor's state decides not to prosecute the agents, perhaps as part of a diplomatic resolution of the incident, the violation remains and begs resolution, leading to the possibility that the offended state will request the extradition of the agents involved. However, extradition requires that prosecution of these government agents under municipal law be consistent with the prosecuting state's obligations under international law. The discussion must now turn to this question.

97. Bassiouni believes return of an abducted person is not recognized as a remedy, given municipal courts' decisions to the contrary. BASS1oun1, supra note 10, at 217. Lawrence Preuss more accurately distinguishes between municipal and international law, stating that although municipal courts may refuse to release the abducted person, the executive branch may still be obligated to correct the breach of international law. Preuss, supra note 89, at 505 n.15.

98. United States v. Alvarez-Machain, 112 S. Ct. 2188, 2196 \& n.16 (1992).

99. See de Schutter, supra note 76 , at 107.

100. Preuss, supra note 96, at 123.

101. Allemagne et Brésil, 13 Revue Générale de Droit International Public [R. Gen. D. INT'L PUB.] 200, 202 (1906); see also OPPENhEIM, supra note 82, pt. 1, § 165 n.7. Other foreign cases involving punishment of government agents by their own governments include an 1884 case in which German officers were punished after arresting a man in Switzerland without the Swiss government's consent, and an 1886 case in which Italian officers arrested a man in Switzerland, again without the Swiss government's consent. 3 TRAVERS, supra note $67, \S 1302(\mathrm{X})$.

102. Breaches by Civil Authorities, 2 Hackworth DigesT $\S 151$, at 320.

103. Id.; $c f$. United States v. Reed, 639 F.2d 896, 902 (2d Cir. 1981) (allowing jurisdiction under Ker where the Bahamas did not protest U.S. government agents' action of luring a U.S. citizen onto a plane in Bimini and subsequently arresting him). 


\section{International Law Regarding Prosecution of Government Agents for Municipal Law Violations: The Schooner Exchange, Alexander McLeod, and the Rainbow Warrior}

Where a state has not given its express consent to the acts of another state on its territory, The Schooner Exchange indicates that immunity will depend on implied consent, determined by looking to custom accepted as law. Customarily, states treat heads of state, ${ }^{104}$ diplomats, ${ }^{105}$ military forces, and warships, when on their territories by mutual agreement, as enjoying a representational capacity as arms of a sovereign. ${ }^{106}$ As such, they are considered immune from the jurisdiction of local courts. ${ }^{107}$ This implied consent to immunity has also been acknowledged for a limited class of other government functionaries. ${ }^{108}$ A special case arises with respect to military forces. While the individuals in a military force on another state's territory by agreement are immune from local jurisdiction by implied consent, ${ }^{109}$ individuals in military forces present without consent are also immune, given that the laws of war would ordinarily apply and absolve individuals of responsibility except in cases of war crimes. ${ }^{110}$

The most famous example of individual immunity from prosecution for state acts in the context of military force arose where the New York

104. For a discussion of head of state immunity in U.S. law, see United States v. Noriega, 746 F. Supp. 1506, 1519-21 (S.D. Fla. 1990); see also Jerrold L. Mallory, Note, Resolving the Confusion Over Head of State Immunity: The Defined Rights of Kings, 86 CoLUM. L. REv. 169, 171-79 (1986).

105. See OpPenheim, supra note 82 , pt. $1, \S 162$. Diplomatic immunity was codified in the Vienna Convention on Diplomatic Relations, Apr. 18, 1961, arts. 1, 29, 37, 38, 23 U.S.T. 3227, 323031, 3240, 3244-45, 500 U.N.T.S. 95, 96-98, 110, 116, 118. See also Vienna Convention on Consular Relations and Optional Protocol on Disputes, Apr. 24, 1963, 21 U.S.T. 77, 596 U.N.T.S. 261; B.J. George, Jr., Diplomatic and Consular Immunity, in INTERNATIONAL CRIMINAL LAw: A GuIDE TO U.S. Practice AND Procedure 395, 400-01 (Ved P. Nanda \& M. Cherif Bassiouni eds., 1987). The usual sanction against diplomats for breaking municipal law is revocation of diplomatic credentials and expulsion from the host state. See generally Bradley Larschan, Comment, The Abisinito Affair: A Restrictive Theory of Diplomatic Immunity?, 26 COLUM. J. TRANSNAT'L L. 283 (1988) (discussing attempted prosecution of diplomat in the United States after credentials were revoked for actions taken while accredited).

106. Ingrid Delupis, Foreign Warships and Immunity for Espionage, 78 AM. J. INT'L L. 53, 5457 (1984).

107. The Schooner Exchange v. M'Faddon, 11 U.S. (7 Cranch) 116, 145-46 (1812) (state ships); OPPENHEIM, supra note 82 , pt. $3, \S \S 492-498,510-514,556-558,560-565$ (respectively, diplomatic agents, embassy personnel other than diplomatic agents, armed forces, and state ships).

108. See OPPENHEIM, supra note 82 , pt. $3, \S \S 566-571$ (political agents, commercial agents, members of commissions, observers, and inspectors, but not spies); Sompong Sucharitkul, Immunities of Foreign States Before National Authorities, 149 RECUEIL DES COURS 87, 99-108 (1977) (subdivisions, essential parts of central government, public corporations).

109. The respective rights of the sending and receiving states have also been made the subject of express agreements. E.g., Agreement Between the Parties to the North Atlantic Treaty Regarding the Status of their Forces, June 19, 1951, art. VII, para. 3, 4 U.S.T. 1792, 1800, 197 U.N.T.S. 67, 76, 78 (allowing U.S. forces in Europe to be tried by U.S. tribunals under certain circumstances); see also Wilson v. Girard, 354 U.S. 524, 526-29 (1957) (per curiam) (interpreting identical provisions of the Status of Forces Agreement between the United States and Japan).

110. See Delupis, supra note 106 , at 55,61 . 
state courts attempted to prosecute Alexander McLeod in $1840 .^{111}$ McLeod was alleged to have been involved in the destruction of the Caroline, a ship which Americans had been using to supply rebels in Canada from a base in the United States. The incident occurred during the early morning hours of December 30,1837, when a detachment of over sixty men from a larger British force in Canada crossed a river marking the U.S.-Canada border and took the Caroline. The detachment set the Caroline on fire and set it adrift, allowing it to plunge over Niagara Falls. ${ }^{112}$

In November 1840, state authorities in New York arrested Alexander McLeod and held him for trial for the murder of a crew member who was shot during the incident. Shortly after McLeod's arrest, and before the New York Supreme Court heard McLeod's petition for habeas corpus, the British Minister to Washington, H.S. Fox, demanded McLeod's release given that the act was carried out by people authorized to defend Britain's territory and citizens. Fox stated that "[i]t would be contrary to the universal practice of civilized nations to fix individual responsibility upon persons who with the sanction or by the orders of the constituted authorities of a State engaged in military or naval enterprizes [sic] in their country's cause."113 In reply, Secretary of State Daniel Webster separated the question of whether the attack was justifiable as self-defense or not, ${ }^{114}$ and, while agreeing with Fox that individuals should not be tried for an act of public force, stated that the federal government could not intervene in the New York state proceeding against McLeod. ${ }^{115}$ The Supreme Court of Judicature of the State of New York

111. 29 British \& Foreign State Papers 1840-1841, at 1126-42 (1857) [hereinafter STATE PAPERS].

112. The larger British military contingent, numbering $2500 \mathrm{men}$, had been assembled largely out of civilian volunteers to repel the actions by U.S. citizens. The facts of this case are recounted in more detail in People v. McLeod, 25 Wend. 483, 484-88 (N.Y. Sup. Ct. 1841); Destruction of the "Caroline," supra note 87, at 409-10; R.Y. Jennings, The Caroline and McLeod Cases, 32 AM. J. INT'L L. 82, 83-84 (1938).

113. Letter from H.S. Fox, British Minister to Washington, to Secretary of Statc Daniel Webster (Mar. 12, 1841), in STATE PAPERS, supra note 111, at 1126-27. Fox also made a barely veiled threat, stating that the fact that McLeod was not involved in the destruction of the Caroline would "necessarily tend greatly to inflame that national resentment which any harm that shall be suffered by Mr. McLeod at the hands of the authorities of New York, will infallibly excite throughout the whole of the British empire." Id. at 1129.

114. See Letter from Secretary of State Daniel Webster to H.S. Fox, British Minister to Washington (Apr. 24, 1841), in STATE PAPERS, supra note 111, at 1129, 1131-33; see also Letter from Secretary of State Daniel Webster to Attorney-General John J. Crittenden (Mar. 15, 1841), in STATE PAPERS, supra note 111, at 1139, 1140-41 (relating position taken with British government).

115. Letter from Secretary of State Daniel Webster to H.S. Fox, British Minister to Washington, supra note 114, at 1131-32. Webster did engage Mr. Crittenden, the Attorney-General, to help McLeod with his defense in the state court. Letter from Secretary of State Daniel Webster to Attorney-General John J. Crittenden, supra note 114, at 1141-42. Because of this incident, Congress passed an act in 1842 providing for the removal to federal courts of any cases involving the sanction of foreign states and the law of nations. Rev. Stat. $\S 753$ (1873-1874); see also Governmental Acts, 2 Moore Digest §179, at 25, 30. 
denied McLeod's petition, refusing to acknowledge the act as a state act. $^{116}$ Rather than bring a habeas corpus proceeding in federal court, McLeod took the case to trial, where he was acquitted and released. ${ }^{117}$

While the McLeod case may be read to exempt all government agents from prosecution for public acts recognized as such by the sponsoring state, the case seems more hikely to apply only in the more limited context of government agents making up military forces. McLeod, though a civilian volunteer, was nevertheless a member of an armed force under a military commander, identified by the British as being charged with the defense of British territory. The destruction of the Caroline was not a case of law enforcement, but was rather an open act of military force. Moreover, Webster and Fox's discussion of the matter took place completely within the context of a use of armed force, without mentioning the possibility that a nonmilitary action by government agents would also be immune from scrutiny by local courts. ${ }^{118}$ Thus, while the McLeod case indicates that a state can impart sovereign immunity to military personnel by assuming responsibility, extension of the McLeod precedent to any government agent engaging in any kind of state action is unsupported by the facts of the case.

Extending $M c L e o d$ to cover any actions of any government agent is especially questionable where the agents are not performing acts of a public international character or acts which are necessary to the conduct of foreign relations - such as military action or diplomatic service ${ }^{119}$ but are rather engaging in law enforcement. Law enforcement activities are not acts of a public international character. While law enforcement necessarily involves the internal aspects of a state's sovereignty-the supremacy of its authority within its own territory-it does not necessarily implicate the external aspects of a state's sovereignty, its right to function as an independent and equal member of the international legal

116. See McLeod, 25 Wend. at 603. Judge Tallmadge of the Superior Court of the City of New York took the somewhat unusual action of writing a "review" of the Supreme Court's opinion in order to correct the state record on the law of nations. Daniel B. Tallmadge, Review of the Opinion of Judge Cowen of the Supreme Court of the State of New-York [sic], 26 Wend. 663, 663 n.* (1841). After a scathing criticism of the Supreme Court, Tallmadge concluded, "[w]e here dismiss this subject, hoping, for the character of our country, that the judgment of the supreme court may be reviewed, and an opinion so unsound in all its parts . . . rendered nugatory as an authority for the future." Id. at 699 .

117. Jennings, supra note 112 , at 95 .

118. See Letter from H.S. Fox, British Minister to Washington, to Secretary of State Daniel Webster, supra note 113, at 1127 (contending that it was "justifiable employment of force for the purpose of defending the British territory"); Letter from Secretary of State Daniel Webster to H.S. Fox, British Minister to Washington, supra note 114, at 1131 (contending that it was "an act of public force"); Letter from Secretary of State Daniel Webster to Attorney-General John J. Crittenden, supra note 114, at 1140 (reporting that it was "an act of public force, done by military men").

119. Regarding the functional basis of diplomatic immunity, see George, supra note 105, at 39697. 
order. $^{120}$

In any case, sovereign immunity is not recognized for all government agents who violate the municipal law of other states. Spies, for example, generally do not benefit from sovereign immunity. ${ }^{121}$ Spies or other secret agents collecting information covertly in other countries are, no doubt, agents of the state that sent them but are not considered to be immune from local jurisdiction if caught and are frequently subject to severe punishment for breach of local laws. ${ }^{122}$

Since the expressly recognized immunities appear to have definite limits, and prosecution of some government agents has been accepted by the international community, it cannot be assumed that all government agents are exempt from prosecution for violations of municipal law. Where, then, does this leave law enforcement officers who have carried out a transborder abduction?

The sparse commentary that directly addresses the question indicates that law enforcement officers would not be immune under customary international law. One commentator suggested that the sponsoring state should extradite the offending individuals but did so without extensive discussion of precedent, leaving it unclear whether he was referring only to private citizens or to both private citizens and government agents. ${ }^{123}$ The only clear indication from treaty law can be found in a protocol to an extradition treaty between Great Britain and Romania, specifically excepting government agents from extradition for trans-

120. See Bernard Gilson, The Conceptual System of Sovereign EQuality 44-45, 55 (1984); see also Hearing, supra note 2, at 62, 64 (statement of Abraham D. Sofaer, Legal Adviser to the State Department) (maintaining that the exercise of U.S. power in situations like the naval campaign against the Barbary pirates can be distinguished from acts of law enforcement) ("All those events were acts of war and foreign diplomacy."); OPPENHEIM, supra note 82, pt. 1, § 117 (equating sovereignty with independence, which has an internal and external aspect).

121. See Pugh, supra note 88, at 661-62 (suggesting that immunity has not been established "for perpetrators and instrumentalities making unauthorised, illegal entries with the official purpose of committing unlawful acts").

122. See OPPENhE1M, supra note 82, pt. 3, § 569; Delupis, supra note 106, at 69-71; see also Quincy Wright, Espionage and the Doctrine of Non-Intervention in Internal Affairs, in QuiNCY WRIGHT ET AL., ESSAYS ON ESPIONAGE AND INTERNATIONAL LAW 3, 12-13 (Roland J. Stanger ed., 1962) ("There is no rule of international law which forbids a state to punish individuals who seek to obtain classified documents, who penetrate forbidden areas, ... or who engage in seditious or other activities -which it has made illegal."); $c f$. Richard R. Baxter, So-Called "Unprivileged Belligerency": Spies, Guerrillas, and Saboteurs, 1951 BRIT. Y.B. INT'L L. 323, 329-33 (suggesting that, according to Hague convention on espionage, spying is not an international crime and local punishment is merely of deterrent effect). Although it has been argued that immunity should apply where spying was not performed covertly or where the sponsoring state claimed responsibility, see Delupis, supra note 106, at 69 ; Morgan, supra note 84 , at 33 , the issue of immunity has by no means been settled, and the few cases on point indicate that immunity will not be recognized. For example, Francis Gary Powers was convicted of spying and sentenced to 10 years' imprisonment by a Soviet court even after the United States claimed responsibility. See Oliver J. Lissitzyn, Some Legal Implications of the $U-2$ and $R B-47$ Incidents, 56 AM. J. INT'L L. 135, 135 (1962); Pugh, supra note 88 , at 661 .

123. See O'Higgins, supra note 95, at 319. 
border abductions performed in the course of their duties. ${ }^{124}$ While it may be argued that such a protocol was a codification of international custom at the time, the scarcity of materials indicating such a custom suggests rather that the exemption for government agents was either a novel approach or possibly even an exception to a custom permitting extradition of government agents.

The difficulty of determining the limits of immunity for state-sponsored acts was especially apparent in the Rainbow Warrior affair, where municipal prosecution of clandestine government agents went forward even though the sponsoring state acknowledged its responsibility. ${ }^{125}$ In July 1985, a team of agents from France's Directorate General for External Security placed and detonated two explosive charges on the Rainbow Warrior, a Netherlands registry ship owned by Greenpeace and berthed in Auckland, New Zealand. The ship sank immediately. Afterwards, authorities arrested two of the agents, Mafart and Prieur, who held commissions in the French Armed Forces, and charged them with crimes relating to the incident, including the murder of a crew member who drowned as the ship sank. Although the French government claimed responsibility, Mafart and Prieur were held for trial by New Zealand, eventually pleaded guilty to lesser offenses, and were sentenced to concurrent terms of ten and seven years by a New Zealand court. ${ }^{126}$

Subsequently, New Zealand and France submitted their dispute over compensation for the act of sabotage to the Secretary General of the United Nations, Javier Pérez de Cuéllar, for resolution. ${ }^{127}$ With respect to claims by New Zealand against France, the Secretary General awarded New Zealand $\$ 7$ million as compensation and ordered France to make a formal apology. ${ }^{128}$ With respect to Mafart and Prieur, the Secretary General rejected France's argument that government agents should be immune from prosecution and ordered, without significant discussion, that they serve three years as the balance of their sentences in French custody on the island of Hoa, a French possession in the South

124. Protocol Explaining Section 21, Article II of the Treaty of Extradition, Mar. 13, 1894, U.K.-Rom., in 9 THE STATUTORY RULES \& ORDERS AND STATUTORY INSTRUMENTS REVISED 348 (1951):

The fact of having kidnapped or falsely imprisoned one or more persons will not admit of a requisition for extradition being made unless the act shall have been committed by private individuals. No such requisition can be made as against public functionaries who may have been guilty of the act in question while in the performance of their duties.

Id.

125. See Regina v. Mafart, 74 I.L.R. 241, 250 (N.Z.H.C. 1985). For the facts of the case, see $i d$. at $245-48$.

126. Id. at $243-45,256$.

127. Ruling Pertaining to the Differences Between France and New Zealand Arising from the Rainbow Warrior Affair, 74 I.L.R. 256 (U.N. Sec. Gen. 1987).

128. Id. at 271. 
Pacific. ${ }^{129}$ Although the value of this ruling as precedent is diminished by its extensive reliance on the Secretary General's notion of justice between the parties, rather than on principles of law, ${ }^{130}$ Rainbow Warrior does indicate that the extent of immunity from municipal prosecution under $M c L$ Leod's umbrella is rather limited.

Thus, assuming that immunity requires a state's implicit consent as indicated by its acceptance of a government agent's presence and role in its territory, a state government reasonably could, consistent with its obligations under international law, prosecute foreign government agents who break its mumicipal law by entering its territory and engaging in law enforcement actions without its consent. Although the prosecution could be waived as part of a diplomatic settlement, the offended state could insist on prosecuting the violation of its municipal law. If it so insists, the offended state could demand extradition in order to bring the offending agents under the adjudicatory jurisdiction of the state's courts. As the next Section shows, both U.S. and foreign municipal law allow the extradition and prosecution of governinent agents under such circumstances.

\section{III \\ EXTRADITION OF GOVERNMENT AGENTS UNDER Municipal and Treaty LaW}

\section{A. U.S. Municipal Law}

Precedent and other analysis of the extradition of government agents under U.S. law is slight, making it difficult to ascertain clear doctrinal underpinnings for the assertion that government agents are not excepted from extradition under municipal law. The writing on the subject that does exist indicates that no exception for government agents engaged in cross-border abductions has yet been recognized and that the trend is against such an exception.

\section{U.S. Treatment of U.S. Government Agents}

a. Statutory Limits on Authority and the Extradition Process

Although a federal agency's authorizing legislation may authorize the agency to conduct extraterritorial activity under the laws of the

129. Id. at 272. Mafart and Prieur later returned to France prior to the expiration of their sentences without the consent of New Zealand. Rainbow Warrior (N.Z. v. Fr.), 82 I.L.R. 500, 523, 540-41 (Fr.-N.Z. Arb. Trib. 1990). On the complaint of New Zealand, an arbitral tribunal held 2-1 that while France violated its obligation to hold Mafart and Prieur for three years, their return to Hoa was a moot question given that the three-year period for which Mafart and Prieur were to be held had expired. Id. at 566-68. The tribunal also held that the declaration that France violated its obligation constituted appropriate satisfaction for New Zealand's legal and moral damages. Id. at 577.

130. See Pugh, supra note 88 , at 656,668 . 
United States, ${ }^{131}$ it cannot exempt U.S. government agents from the laws of a foreign state. If such legislation exempts U.S. government agents from the application of U.S. law in order to facilitate law enforcement activity, it does so only under United States law, but not under the laws of foreign countries. ${ }^{132}$ Since U.S. government agents are thus arnenable to foreign prosecution regardless of authorizing legislation, ${ }^{133}$ a court faced with the question of extraditing government agents for a cross-border abduction could only deny extradition when the authorizing legislation also exempts government agents from the extradition process.

Such an exemption, however, has never been statutorily authorized. United States Code sections dealing with extradition do not exempt U.S. government agents or agents of the states of the Union. ${ }^{134}$ In fact, an extradition magistrate or district court judge need only deem "the evidence sufficient to sustain the charge under the provisions of the proper treaty or convention" in order to certify extradition to the Secretary of State. ${ }^{135}$ Case law interprets this to inean that the extradition hearing is not a trial on the merits but rather requires the requesting state to meet an evidentiary burden similar to that of a preliminary liearing-a showing of probable cause to believe that the person before the court is the

131. See Andrew G. McBride, Special Assistant U.S. Att'y, E. Dist. Va., Prepared Statement Before the Subcomm. on Civil and Constitutional Rights of the House Judiciary Comm. 2-5 (July 24 , 1992) (unpublished manuscript, on file with author) (arguing that FBI authorizing statutes, 18 U.S.C. § 3052 (1988), 28 U.S.C. § 533(1) (1988), impliedly contain such authority).

132. See Abraham D. Sofaer, Legal Adviser of the Department of State, Prepared Statement on the International Law and Foreign Policy Implications of Nonconsensual Extraterritorial Law Enforcement Activities Before the Subcomm. on Civil and Constitutional Rights of the House Judiciary Comm. 1-2, 14-15 (Nov. 8, 1989) (unpublished manuscript, on file with author) (distinguishing the consequences of cross-border abductions in U.S. law, given extraterritorial authority of the FBI, from consequences in other countries' legal systems and in international law).

133. Other legislation, however, may prohibit U.S. government agents from conducting arrests abroad despite the existence of authorizing legislation. For example, the Mansfield Amendment to the Foreign Assistance Aćt states that "[n]o officer or employee of the United States may directly effect an arrest in any foreign country as part of any foreign police action with respect to narcotics control efforts, notwithstanding any other provision of law." 22 U.S.C. $\$ 2291$ (c)(1) (Supp. III 1991). The Amendment does not, however, prohibit the presence of officers or employees of the United States at arrests effected by foreign officers. Id. \$2291(c)(2). But see United States v. Zabaneh, 837 F.2d 1249, 1261 (5th Cir. 1988) (finding that alleged violation of the Mansfield Amendment could not void the court's jurisdiction because the amendment does not provide for such a sanction); see also Lowenfeld, supra note 45 , at $477-81$ (detailing the legislative history of the Mansfield Amendment).

134. See 18 U.S.C. $\S \S 3181-3195$ (1988 \& Supp. IV 1992). The current extradition statutes were enacted by the Act of June 25, 1948, Pub. L. No. 772, pt. 1, ch. 645,62 Stat. 821-25, and made only minor changes to preceding extradition laws originally enacted by the Act of Aug. 12, 1848, ch. 167, 9 Stat. 302-03 (codified at Rev. Stat. $\$ \S 5270-5278$ (1878), 18 U.S.C. $\$ \S 651-668$ (1988)). For a comparative treatment of the extradition process, including historical development, see $5 \mathrm{~J}$.H.W. Verzijl, InTernational Law in Historical Perspective 270-86 (1972); see also David M. Kennedy et al, The Extradition of Mohammed Hamadei, 31 HARV. INT'L L.J. 5, 12-20 (1990) (describing extradition under treaty between former Republic of West Germany and United States).

135. 18 U.S.C. $\$ 3184$ (Supp. IV 1992); see RESTATEMENT, supra note 86, § 478. 
person sought and that she committed the crime. ${ }^{136}$ The requesting state must also show that the person before the court is the person for whom extradition is requested, that a valid treaty exists, and that extradition is proper under the treaty. ${ }^{137}$ The only review of a court's warrant of extradition is a mandatory one by the Secretary of State, ${ }^{138}$ and thus, there is no appeal per se. The court's decision, however, can be reviewed in a habeas corpus proceedimg. ${ }^{139}$

Accordingly, defenses in an extradition proceeding are limited. Since the proceeding resembles a preliminary hearing, evidence going to the merits of the case, including exculpatory or justificatory evidence, may not be heard, and any evidence in defense must go towards the application of the treaty itself or explain the prima facie evidence.

While the accused may introduce evidence to show that the case comes within a prohibition against extradition contained in the applicable treaty and/or law ... or to show that he is not, in actuality, the person sought by the requesting State, he may not, generally, introduce evidence in defense to the merits of the charge or merely to contradict the evidence of guilt submitted by the requesting State. ${ }^{140}$

Statutory extradition law thus indicates not only that status as a government agent does not allow an explicit exemption, but also that government agent status, at least in reference to the merits of the case, might not even be cognizable in an extradition proceeding.

\section{b. Case Precedent}

An exemption from extradition treaties for U.S. government agents also finds little support in case precedent. Indeed, when the federal courts directly confronted the question in the cases of Collier $v$.

136. See Chariton v. Kelly, 229 U.S. 447, 458 (1913); Glucksman v. Henkel, 221 U.S. 508, 512 (1911) (Holmes, J.); Benson v. MċMahon, 127 U.S. 457, $462-63$ (1888); Escobedo v. United States, 623 F.2d 1098, 1101-02 (5th Cir.), cert. denied, 449 U.S. 1036 (1980), and cert. denied, 450 U.S. 922 (1981); Garcia-Guillern v. United States, 450 F.2d 1189, 1191 (5th Cir. 1971), cert denied, 405 U.S. 989 (1972); Hearing, 6 Whiteman DigEST $§ 28$, at 944-45, 975; see also OPPENHEIM, supra note 82 , pt. $3, \S \$ 419-420$ (discussing general procedure for extradition among states); VERzIJL, supra note 134 , at $318-19$ (same).

137. Hearing, supra note 136 , at 944-45; see also RESTATEMENT, supra note $86, \S 476$ (listing similar exceptions to extradition).

138. See 18 U.S.C. $\$ \S 3184,3186$ (1988 \& Supp. IV 1992).

139. Habeas corpus inquiry is usually restricted to (1) whether the committing magistrate or judge had subject matter and personal jurisdiction, (2) whether the offenses charged are cognizable under the treaty, and (3) whether the evidence warranted a finding that there is reasonable ground to believe the accused guilty. Fernandez v. Phillips, 268 U.S. 311, 312 (1925); Ahmad v. Wigen, 910 F.2d 1063, 1064 (2d Cir. 1990); Collier v. Vaccaro, 51 F.2d 17, 20 (4th Cir. 1931).

140. Evidence in Defense, 6 Whiteman DIGEST $\S 32$, at 998-99; see also Collins v. Loisel, 259 U.S. 309, 316 (1922); Charlton, 229 U.S. at 462; Desmond v. Eggers, 18 F.2d 503, 505-06 (9th Cir. 1927); In re Shapiro, 352 F. Supp. 641, 644-45 (S.D.N.Y. 1973); RESTATEMENT, supra note 86, $\S 476 \mathrm{cmt}$. b; BASSIOUN1, supra note 10 , at 558 . 
Vaccaro $^{141}$ and Extradition of Mertz, ${ }^{142}$ they held that extradition could proceed regardless of the defendants' status as U.S. government agents.

In 1925, Mertz, an agent of the Narcotics Bureau of the Treasury Department, and Vaccaro, an informer employed by the Bureau, were investigating a smuggling ring led by a Canadian citizen named Price. ${ }^{143}$ Under an agreement between their superior and the head of narcotics enforcement in Canada, Mertz and Vaccaro conducted part of their investigation in Canada. While in Canada, they arranged to purchase narcotics from Price in the United States, a few miles from the international border. Price's accomplices, Bilodeau and Nadeau, delivered the narcotics while Price waited in a "line house"-a bar directly on the international border. The agents, anxious to arrest Price, took Bilodeau with them to the line house to lure Price into the United States. During the arrest, however, a fight broke out, and as Bilodeau tried to escape, Mertz shot and killed him. Price was apprehended and taken to stand trial in the United States.

In 1930, the Canadian government, under the impression that the events had taken place on the Canadian side of the border, requested the extradition of Vaccaro for murder, larceny, and kidnapping, although the extradition commissioner ordered that Vaccaro be extradited only on the charges of murder and kidnapping. ${ }^{144}$ On Vaccaro's application for a writ of habeas corpus, the district court ordered his release. The court found that even if the acts did occur in Canada, they were legally justified as arrests of a person committing a felony, and thus, there was no reason to believe a crime had been committed. ${ }^{145}$ On appeal, the Fourth Circuit rejected this reasoning, holding that Vaccaro had no legal right to carry Price out of Canada. ${ }^{146}$ Citing to a Canadian statute specifically prohibiting carrying a person out of Canada against her will, the court distinguished lawful arrests from cross-border abductions, stating that while arrests can be carried out with or without a warrant, or by people who are not police officers,

[a] person may be carried out of the country to answer for crime,

141. 51 F.2d 17 (4th Cir. 1931).

142. 52 F.2d 241 (S.D. Tex. 1931).

143. Id. at 244-45; see also Weight and Effect of Evidence, 4 Hackworth Digest § 331, at 16163 (recounting facts of case); Alona E. Evans, Acquisition of Custody over the International Fugitive Offender-Alternatives to Extradition: A Survey of United States Practice, 1964 BRIT. Y.B. INT'L L. 77, 91-92 (same).

144. Collier, 51 F.2d at 18.

145. More specifically, the court held that Vaccaro, indeed anyone, could arrest any person engaged in the commission of a felony and use force to stop the arrested person from escaping. The district court also found that the murder charge could not stand because Vaccaro could not be considered an accomplice to Mertz's shooting of Bilodeau. Vaccaro v. Collier, 38 F.2d 862, 868 (D. Md. 1930), aff'd in part and rev'd in part, 51 F.2d 17 (4th Cir. 1931).

146. Collier, S1 F.2d at 19. On the murder charge, the court agreed with the district court that Vaccarro did not aid or abet Mertz. Id. 
however, only by the authority of the highest executive officials and in accordance with treaty provisions governing extradition. An unlawful arrest is merely an offense against the peace and dignity of the state; an unlawful carrying of a citizen beyond its boundaries to be dealt with by the laws of another state is a violation of the sovereignty of the former. ${ }^{147}$

The court did mention that the Secretary of State was not bound to deliver Vaccaro to Canada and could, on his review of the case, refuse to extradite. ${ }^{148}$ This is in fact what happened when Secretary of State Cordell Hull finally disposed of the case in a 1934 letter to the Minister of Canada. ${ }^{149}$ Noting the agreement between U.S. and Canadian officials regarding the investigation, the approval of Price's arrest by the head of Canadian narcotics enforcennent, and the conflicting evidence as to which side of the border the acts took place on, Secretary Hull refused to order Vaccaro's extradition. ${ }^{150}$

Neither the district court, the appeals court, nor Secretary Hull once suggested that Vaccaro's status as a U.S. government agent might, in and of itself, exempt him from extradition proceedings. While Secretary of State Hull's refusal to order extradition was, in part, based on the agreeinent between the law enforcement officials of the two countries, it was not based on Vaccaro's status as a U.S. governinent agent. Similarly, the district court reviewing Mertz' case also failed to mention his status as a U.S. government agent. ${ }^{151}$ Thus, Collier and Mertz, the only two cases on point, provide no indication that U.S. law exempts U.S. government agents from extradition. Nor do the cases imply that if the arrest had been authorized by the U.S. government, the agents would have been iminune. Although internal meinoranda in the State Department apparently raised the issue and concluded that the arrest was not authorized, ${ }^{152}$ neither court distinguished between authorized and unauthorized arrests.

Villareal v. Hammond ${ }^{153}$ also supports the principle that government agents are not exempt from extradition for cross-border abductions. Although the case was apparently decided on the assuinption that the

147. Id.

148. Id. at 20-21. The court specifically excluded itself from an exercise of discretion in this area, stating, "This ... is a matter for the executive to pass upon and not for the courts." Id. at 21.

149. See Weight and Effect of Evidence, supra note 143, at 162-63.

150. Id.

151. The district court judge refused to warrant Mertz's extradition for murder because he did not believe the shooting took place in Canada but impliedly could have extradited Mertz if it had. See Extradition of Mertz, 52 F.2d 241, 243, 246 (S.D. Tex. 1931).

152. Evans, supra note 143, at 92 n.2. G.H. Hackworth, Legal Adviser to the State Department at the time, did not mention these memoranda or the question of authorization in his discussion of the case in his Digest of International Law. See Weight and Effect of Evidence, supra note 143, at 161-63.

153. 74 F.2d 503 (5th Cir. 1934). 
defendants were acting as private citizens, ${ }^{154}$ the circumstances of the abduction raise some indication of governnent connivance. Villareal arranged, presuniably with federal authorities, to place a reward in an escrow account for the detivery of the abducted person. ${ }^{155}$ Moreover, Lopez was delivered directly to a waiting U.S. deputy marshal in Laredo, Texas. ${ }^{156}$ Despite Lopez' "delivery to justice," his kidnappers were extradited to Mexico.

\section{c. Legal Opinion}

The legal opinions of the United States government on cross-border abductions serve as additional evidence of what the United States considers its legal obligations to be. Recent statenients of the Legal Adviser to the State Departınent indicate that the United States does not believe inınunity attaches to nonnilitary U.S. government agents for violations of foreign municipal law and recognizes that such agents performing abductions abroad can be subject to foreign prosecution. In 1986, during hearings on the Onınibus Diplomatic Security and Antiterrorisn 1 Act, ${ }^{157}$ Legal Adviser Abraham D. Sofaer stated, "I would say that seizure by U.S. officials of terrorist suspects abroad . . could violate local kidnaping laws-that is, the people who do the seizing could be, in fact, crininals under local law." 158 In 1989, reviewnig the assertion by the Justice Department that the F.B.I. had legislative authority to conduct extraterritorial arrests, he stated:

Our agents would not normally enjoy immunity from prosecution or civil suit in the foreign country involved for any violations of local law which occur. . . . The United States could also face requests from the foreign country for extradition of the agents. Obviously, the United States would not extradite its agents for carrying out an authorized mission, but our failure to do so could lead the foreign country to cease extradition cooperation with us. Moreover, our agents would be vulnerable to extradition fron third countries they visit. ${ }^{159}$

Sofaer's assertion that U.S. government agents would not be extradited, as an opinion from the Executive Branch, is not determinative of

154. See supra text accompanying notes 64-67.

155. $74 \mathrm{~F} .2 \mathrm{~d}$ at 504-05. There is a close similarity in this respect to Accredited's agreement with the Putnam County prosecutor and county court pursuant to which Accredited effected Sidney Jaffe's abduction. See supra note 29 and accompanying text.

156. Ex parte Lopez, 6 F. Supp. 342, 343 (S.D. Tex. 1934).

157. Pub. L. No. 99-399, tit. XII, $\$ 1202$ (a), 100 Stat. 853, 896 (1986) (codified at 18 U.S.C. $\S 2332$ (Supp. IV 1992)); see also Andreas F. Lowenfeld, U.S. Law Enforcement Abroad: The Constitution and International Law, 83 AM. J. INT'L L. 880, 890 (1989) (reviewing background and implications of the Act).

158. Hearing, supra note 2 , at 63.

159. Sofaer, supra note 132 , at $14-15$. 
how the judiciary would resolve the question. It is, in any case, couched in terms of political discretion rather than legal obligation. Instead of stating that the United States has no obligation to extradite agents who committed illegal acts in another country, he indicates that extradition would be flatly refused, presumably at the discretion of the Executive Branch rather than by a court interpreting an extradition treaty. Thus, Sofaer's testimony is consistent with the outcome of Collier: political discretion will resolve the political problems of extradition of government agents regardless of the legal disposition of the case.

This review of federal precedent indicates that U.S. law has not yet recognized an exception to extradition or prosecution for U.S. government agents performing seizures abroad. Thus, a court reviewing such a case could, consistent with such precedent, warrant the extradition of U.S. government agents.

\section{U.S. Treatment of Foreign Government Agents}

The legal treatment by the United States of foreign government agents who have carried out law enforcement acts in the United States also indicates that a federal court could warrant the extradition of U.S. government agents. This follows from the logic of reciprocity: since the United States has asserted a right to seek the prosecution or extradition of foreign government agents for carrying out kidnappings, it should not be able to assert immunity in the United States for U.S. government agents who carry out the same acts in other countries. In this context, the McLeod incident stands only for the immunity of foreign government agents who engage in military actions, and not those who attempt to enforce foreign law in the United States. ${ }^{160}$.

The United States openly asserted its right to punish exercises of police power by foreign states in U.S. territory in 1948, when a Soviet Consul in New York attempted to abduct a Soviet defector. ${ }^{161}$ The Legal Adviser of the State Department advised the New York Supreme Court that the right of consuls to aid their citizens "does not include authority to take charge of Soviet citizens in this country irrespective of their wishes." 162 Edwin Borchard, commenting on the incident, stated:

One lesson that the State Department ought to give to all persons concerned in this case is that foreign consuls, including the Russian Consul, do not enjoy extraterritorial control over their fellow nationals in this country and that any attempt at the exer-

160. See supra notes 111-17 and accompanying text.

161. See Note of the Department of State to the Embassy of the USSR, 19 DEP'T ST. BULL. 251,253 (1948) ("[T]he Government of the United States cannot permit the cxercise within the United States of the police power of any foreign government."); Edwin Borchard, The Kasenkina Case, 42 AM. J. INT'L L. 858 (1948).

162. Letter from the Legal Adviser of the Department of State to the Justice of the New York Supreme Court (Aug. 18, 1948), reprinted in 19 DEP'T ST. BuLL. 261, 262 (1948). 
cise of false imprisonment is punishable by American law. ${ }^{163}$

Because of the consular status, and hence immunity, of the abductor, however, the case was never prosecuted. ${ }^{164}$

Where consular, diplomatic, or military immunity is not involved, prosecution of government agents has been freely admitted. Sovereign immunity was not considered in 1952 when agents of the Ministry for State Security of East Germany abducted Dr. Walter Linse, a West German citizen then residing in the American sector of Berlin, and brought him to East Berlin to face trial by a Soviet military tribunal. The U.S. Commandant in Berlin demanded that the Soviet authorities return Linse and extradite the East German agents to West Berlin for prosecution. ${ }^{165}$

Nor did sovereign immunity stop two attempts by the United States to bring foreign government agents to trial in the United States. After agents of the Chilean government assassinated Orlando Letelier in Washington, D.C. in 1976, the United States unsuccessfully sought the extradition of agents froin Chile's Dirección de Inteligencia Nacional, including Army General Manuel Contreras, a former head of that agency. ${ }^{166} \mathrm{~A}$ federal district court trying a civil suit instituted by Letelier's survivors against Chile held that Chile was not entitled to sovereign immunity under the Foreign Sovereign Immunities Act of $1976 .{ }^{167}$ Although discretionary acts of a state immunize the government agents even if they cause personal injury within the United States, ${ }^{168}$ the court held that intentional, illegal acts cannot be discretionary. ${ }^{169}$ Kidnapping,

163. Borchard, supra note 161 , at 859 .

164. For more information on diplomatic and consular immunity, see supra note 105.

165. Letter from General Lemuel Mathewson to S.T.S. Dengin (July 8, 1952), reprinted in 27 DeP'T ST. BULl. 320 (1952); see also Territorial Integrity, 5 Whiteman D1GEST $\$ 11$, at 206-08. Although his abductors were eventually tried, see infra text accompanying note 186, Linse was sentenced to 25 years in prison in 1953 and died later that year. His death did not become public until June 1960, when the German Red Cross announced that it had received notification from the Soviet Red Cross that Linse had died. Territorial Integrity, supra at 207. During the 1989 Congressional hearings on extraterritorial law enforcement, Sofaer cited the Linse incident as indicating that U.S. government agents could be subject to prosecution under local laws. See Sofaer, supra note 132 , at 14 .

166. See Letelier v. Republic of Chile, 488 F. Supp. 665, 666 n.1 (D.D.C. 1980); TAYLOR Branch \& Eugene M. Propper, Labyr1nth 581 (1982). Later cases disagreed with Letelier's holding that actions in foreign countries which give rise to injury in the United States do not give rise to immunity and are not shielded by the act of state doctrine. See Frolova v. U.S.S.R., 761 F.2d 370, 379-80 (7th Cir. 1985); Persinger v. Islamic Republic of Iran, 729 F.2d 835, 842 (D.C. Cir.), cert. denied, 469 U.S. 881 (1984). These later cases would not imply, however, that acts of a foreign state on U.S. territory would be similarly immune or subject to act of state.

167. 28 U.S.C. $\S \S 1602-1611$ (1988 \& Supps. II 1990 \& III 1991).

168. 28 U.S.C. $\$ 1605(a)(5)(A)(1988)$.

169. Letelier, 488 F. Supp. at 673 ("Whatever policy options may exist for a foreign country, it has no 'discretion' to perpetrate conduct designed to result in the assassination of an individual or individuals, action that is clearly contrary to the precepts of humanity as recognized in both national and international law."). 
in most if not all cases, would qualify as an intentional, illegal act, and by the above reasoning, could not give rise to sovereign immunity.

Sovereign immunity may also play a role in the ongoing attempts by the United States and Great Britain to extradite two Libyans for the 1988 bombing of Pan Am Flight 103 over Lockerbie, Scotland. ${ }^{170}$ The continuing legal and diplomatic debate, involving U.N. sanctions against Libya for its refusal to extradite, ${ }^{171}$ is complicated by allegations that the two suspects are intelligence officers of the Libyall government. While to date the Libyan government has neither admitted their status as government agents nor taken responsibility, persistent demands for the extradition of the two Libyans in the face of this possibility suggests that neither the United States or Great Britain would recognize immunity from local jurisdiction in this case. ${ }^{172}$

However, sovereign immunity is not the only doctrine a U.S. court can use to avoid passing judgment on foreign agents. The act of state doctrine might also protect foreign agents who carry out police actions in the United States. Act of state differs from sovereign immunity in that sovereign immunity is a limitation on the jurisdiction of a U.S. court deriving from the identity of the defendant as an arm of a foreign sovereign. Act of state is an aspect of choice of law jurisprudence, requiring a court to refrain from passing on the acts of a foreign sovereign on the sovereign's own territory, on the presumption that those acts are legal under the laws of the foreign country and that judging their legality might embarrass the Executive Branch in its conduct of foreign policy. ${ }^{173}$ As such, it applies whenever a court must judge an act of a foreign sovereign on its territory, regardless of the identity of the defendant. However, the rationale for applying the act of state doctrine disintegrates when the acts are no longer those of a sovereign on its own territory but

170. Requests by the two nations for extradition were refused by a Libyan court on the bases that Libya does not allow its citizens to be extradited involuntarily and that, in any case, Britain and the United States had been unwilling to provide sufficient evidence to warrant extradition. See Ronc Tempest, Libyan Bomb Suspects Appear Before a Judge, L.A. TIMEs, Feb. 19, 1992, at A4.

171. The International Court of Justice was unwilling to order the suspension of these sanctions pending further consideration of the case. Questions of Interpretation and Application of the 1971 Montreal Convention Arising from the Aerial Incident at Lockerbie (Libya v. U.K.), 1992 I.C.J. 3, 15 (Apr. 14); Questions of Interpretation and Application of the 1971 Montreal Convention Arising from the Aerial Incident at Lockerbie (Libya y. U.S.), 1992 I.C.J. 114, 127 (Apr. 14); see also Stanley Meisler, U.N. Court Allows Libyan Sanctions, L.A. Times, Apr. 15, 1992, at A1.

172. In the similar case of Mohammed Hamadei, whom the United States attempted to extradite from West Germany for the hijacking of TWA Flight 847 and shooting of a U.S. Navy diver in 1985, it has been suggested that the McLeod case warrants immunity, unless Hamadei's acts can be characterized as war crimes. See Kennedy et al, supra note 134, at 30-31 \& n.140 (characterizing Hamadei as " $a$ Lebanese individual claiming to act for an organized political body in pursuit of an ongoing military objective abroad").

173. See First Nat'l City Bank v. Banco Nacional de Cuba, 406 U.S. 759, 767-70 (1972); Banco Nacional de Cuba v. Sabbatino, 376 U.S. 398, $427-28$ (1964); Underhill v. Hernandez, 168 U.S. 250, 252 (1897); see also United States v. Noriega, 746 F. Supp. 1506, 1523 (S.D. Fla. 1990) (discussing act of state doctrine). 
acts within the United States. At that point, the acts have no sovereign authority.

\section{B. Foreign Municipal Law}

To the extent that foreign cases also admit the possibility that government agents can be prosecuted for any violations of municipal law they might commit in the course of their carrying out extraterritorial law enforcement actions, foreign cases demonstrate a lack of sovereign immunity for such agents, and hence support the idea that they are amenable to extradition. The New Zealand court ruling against Mafart and Prieur in the Rainbow Warrior case stands as a notorious recent precedent: since a New Zealand court held that they could be prosecuted, presumably it would also hold them extraditable. ${ }^{174}$

Similarly, English law has long recognized the possibility that government agents engaging in abductions can be subject to municipal law proceedings. In Ex parte Scott, ${ }^{175}$ cited in Ker, ${ }^{176}$ a British police officer arrested a fugitive in Brussels and brought her back to Great Britain. Although the court ignored the consequences of that act in international law, it made the municipal law consequences of prosecution and private action very clear, stating, "If the act complamed of were done against the law of a foreign country, that country might have vindicated its own law. If it gave [the country] a right of action, [the country] may sue upon it." 177

English law also permits prosecution of foreign government agents acting in territory subject to its jurisdiction. In Regina v. Lesley, the Chilean government paid a British citizen to carry Chilean political dissidents to Liverpool in his ship. ${ }^{178}$ Although the court recognized that the acts of Chile and its British agent might be lawful within Chile, once the British ship entered the high seas, the ship's captain was liable for false imprisonment under English law regardless of his status as an agent for the Chilean government. According to the court, "for an English ship the laws of Chili [sic], out of the state, are powerless, and the lawfulness of the acts must be tried by English law."179

The question of foreign police actions in British territory also arose

174. See supra text accompanying notes $125-30$.

175. 109 Eng. Rep. 166 (K.B. 1829).

176. Ker v. Illinois, 119 U.S. 436,444 (1886).

177. Scott, 109 Eng. Rep. at 167; see also de Schutter, supra note 76, at 115-16 (noting that British precedent dealt with municipal law, not international law); O'Higgins, supra note 95, at 28288 (same).

178. Regina v. Lesley, 169 Eng. Rep. 1236, 1237-40 (Cr. Cas. Res. 1860).

179. Id. at 1242. Liability of government agents who engage in cross-border abductions was admitted by a Home Office memorandum in 1895, even though it also asserted jurisdiction over abducted fugitives, partiaily on the basis of Ker:

[F]or an English police officer to arrest a criminal in any foreign country without any proceedings authorized by the courts of that country is a breach of the comity of nations, 
in the Soblen case, when the United States sought to bring a fugitive back to the United States from Israel to serve a life sentence for espionage. ${ }^{180}$ On the flight back from Israel, and while accompanied by a U.S. marshal, the defendant caused serious injury to himself, forcing the plane to land in London. ${ }^{181}$ The British government, although it provided for the defendant's medical care, side-stepped the legal problems of having to extradite the defendant by "refus[ing] him leave to land" and did not question the U.S. marshal's continued exercise of control over the defendant. ${ }^{182}$ Paul O'Higgins, reviewing the case, observed that the U.S. marshal had violated English law:

No foreign policeman has any authority to keep anyone in their [sic] custody inside the Umited Kingdom and on the facts [the U.S. marshal] was by his own admission committing the tort of false imprisonment. Ordinarily any police act done by a foreign state on British soil would be a violation of international law, as well as a violation of English municipal law. ${ }^{183}$

Outside of Great Britain, other incidents of extraterritorial law enforcement actions show a similar trend towards prosecuting the officers involved. In the Jacob-Salomar case, ${ }^{184}$ Swiss authorities arrested one of the agents involved in the abduction and held him for trial upon his return to Switzerland, although these proceedings were apparently superseded by the German government's punishment of the agents involved. ${ }^{185}$ Following Walter Linse's kidnapping and the failure of the Soviet authorities to return Linse or to extradite his abductors, authorities in West Berlin eventually arrested, tried, and sentenced two of the abductors for kidnapping, despite their admitted status as agents of East Germany's Ministry for State Security. ${ }^{186}$ A Swiss court tried and convicted two French customs officials, in absentia, for carrying out an investigation in Switzerland. ${ }^{187}$ The court stated that "their official duty

and would subject him to proceedings in that country at the suit or on the prosecution of the person so arrested.

Extradition: Rendition of Fugitive Offenders, supra note 75 , at 485.

180. See United States v. Soblen, 301 F.2d 236 (2d Cir. 1962), cert. denied, 370 U.S. 944 (1962); Paul O'Higgins, Disguised Extradition: The Soblen Case, 27 MOD. L. REV. 521, 530-31 (1964) (summarizing the facts of the case).

181. O'Higgins, supra note 180 , at 531 .

182. Ex parte Soblen, 3 All E.R. 641, 665 (C.A. 1962); see also Ex parte Soblen, 3 All E.R. 373 (C.A. 1962) (related case); O'Higgins, supra note 180, at 532-33 (criticizing court's approval of these actions).

183. O'Higgins, supra note 180, at 532 (footnote omitted).

184. See supra notes $96 \& 100$ and accompanying text.

185. See Preuss, supra note 89, at 503; Preuss, supra note 96, at 123-24 n.5.

186. Investigation of Kidnaping of Dr. Walter Linse, 27 DEP'T ST. BuLL. 823 (1952); Territorial Integrity, supra note 165, at 206-08; see also Sofaer, supra note 132, at 14.

187. Claus Schellenberg, The Proceedings Against Two French Customs Officials in Switzerland for Prohibited Acts in Favor of a Foreign State, Economic Intelligence Service and Violation of the Banking Law, 9 INT'L Bus. LAw. 139, 139-40 (1981). 
came to an end at the frontier of France."188

Lack of immunity for government agents carrying out seizures in foreign countries was the legal position of the government of New Zealand in the Rainbow Warrior incident ${ }^{189}$ and of both Canada and Mexico in response to incursions by the United States. ${ }^{190}$ The Canadian government revealed its position in its amicus brief to the Supreme Court in Alvarez-Machain, in which it stated that "Canada will continue to protest such abductions when they occur and to seek the extradition and prosecution of those responsible, whether they be private individuals or federal, state or local law enforcement officers."191 Of course, such legal positions may be little more than grandstanding since diplomatic resolutions may very well continue to vitiate the obligation to extradite government agents.

Nevertheless, such opinions, as well as foreign precedents, indicate that foreign municipal law does not recognize the official status of government agents who perpetrate abductions in foreign territory. This is true even if such abductions were authorized under the foreign government's laws. As was shown in the previous Section, these holdings are not antithetical to American precedent. In fact, American law appears to be an integral part of this line of municipal law precedent.

\section{Relevant Treaty Law}

Although extradition treaties could potentially be interpreted to exempt government agents who engage in cross-border abductions, such interpretations would constitute an unwarranted broadening of their terms. Government agents performing law enforcement functions abroad are not diplomats, nor are they military forces acting openly as such, nor would they fit into any of the other categories to which immunity is usually applied. In order to include government agents within the

188. Id. at 140 (quoting the Zurich District Court). There are numerous other incidents of municipal prosecution of law enforcement officers. See Espagne et France, 80 R. GEN. D. INT'L PuB. 248 (1976) (discussing case in which Spanish police officer received a two-month suspended sentence for carrying a gun into French territory); France et Italie, 79 R. GEN. D. INT'L PUB. 1159 (1975) (discussing case in which Italian inspector working with French police was indicted for shooting of suspect during arrest); Italie et Suisse, 89 R. GEN. D. INT'L PUB. 460 (1985) (discussing prosecution in Switzerland of two Italian Servizio Informazione di Sicurezza Militare agents for conducting surveillance of Italian national wanted for espionage); Italie et Suisse, 78 R. GEN. D. INT'L PuB. 851 (1974) (discussing arrest of Italian inspector for conducting investigation in Switzerland); see also Joseph M. SweEney ET AL., CaSes AND MATERIALS ON THE INTERNATIONAL LEGAL SYSTEM 137 (3d ed. 1988) (summarizing the above cases).

189. Regina v. Mafart, 74 I.L.R. 241, $242-43$ (N.Z.H.C. 1985); see also supra text accompanying note 126.

190. See Brief of the Government of Canada, supra note 57, at 14; Kreczko, supra note 72, at 12.

191. Brief of the Government of Canada, supra note 57, at 14. Canada's position was also mentioned by the Deputy Legal Adviser to the State Department in a congressional hearing after the Alvarez-Machain decision. See Kreczko, supra note 72, at 8. 
established exemptions from extradition, which are derived largely from immunity from local prosecution, the exemptions would have to be greatly extended, rendering them overinclusive and meaningless.

An abduction carried out by government agents could be viewed as an act undertaken without hope of personal gain and thus similar to a political offense, for which extradition cannot be granted. ${ }^{192}$ However, the political offense exception should not apply because in both international and U.S. mumcipal law an offense is deemed political not simply because the perpetrator had a selfless motive but because it is directed against the security or governmental system of a state. This test is used both for purely political crimes such as treason and for common crimes with a political motive. ${ }^{193}$

Nor do other objections, such as extradition of nationals of the extraditing state or double criminality, serve to prevent government agents from being extradited. The ability of the United States to extradite its own nationals has been well established in American law. ${ }^{194}$ Even if extradition treaties provide that extradition of nationals is discretionary, they will also usually provide for aut dedere aut iudicare (extradite or try). ${ }^{195}$ Neither would double criminality, requiring the offense to

192. See, e.g., Extradition Treaty Between the United States of America and the United Mexican States, supra note 52, art. 5(1) ("Extradition shall not be granted when the offense for which it is requested is political or of a political character."); see also Political Offenses, 6 Whiteman DIGEST $§ 15$, at 800 (discussing exemption for political offenses).

193. See Bassiouni, supra note 10, at 391. Similar views of political offenses can be found in Political Offenses, supra note 192, at 800 , and in Harvard Research in International Law, Draft Convention on Extradition, 29 AM. J. INr'L L. 21, 22, 112-99 (Supp. 1935). Art. 5(b) of this convention reads:

[T] he term "political offense" includes treason, sedition and espionage, whether committed by one or more persons; it includes any offense connected with the activities of an organized group directed against the security or governmental system of the requesting State; and it does not exclude other offenses having a political objective.

Id. at 112-13; see also VERZIJL, supra note 134, at 303-10 (giving historical account of extradition for political offenses). In U.S. law specifieally, the debate centers around the dividing line between political offenses and common crimes. Both camps agree that some sort of political objective is vital to the exception apart from selfless motivation. See Ahmad v. Wigen, 910 F.2d 1063, 1066 (2d Cir. 1990) (noting that "[p]olitical motivation does not convert every crime into a political offense" and holding that attack on a commercial bus carrying civilians on a regular route was not included in political offense exception); In re Doherty, 599 F. Supp. 270, 274 (S.D.N.Y. 1984) (holding that political offenses do not include every act committed for a political purpose or during a political disturbance). But see Quinn v. Robinson, 783 F.2d 776, 796-801 (9th Cir.) (defining political offense as any act for political purpose during war or uprising), cert. denied, 479 U.S. 882 (1986).

194. See Charlton v. Kelly, 229 U.S. 447 (1913); Escobedo v. United States, 623 F.2d 1098, 1106-07 (5th Cir.), cert. denied, 449 U.S. 1036 (1980), and cert. denied, 450 U.S. 922 (1981); Peroff v. Hyiton, 563 F.2d 1099, 1102 (4th Cir. 1977); see also Wilson v. Girard, 354 U.S. 524, 530 (1957) (holding that handing U.S. serviceman to Japanese authorities for trial under Status of Forces agreement not barred by the Constitution); Kester, supra note 10, at 1473-76 (reviewing law allowing extradition of nationals).

195. E.g., Extradition Treaty Between the United States of America and the United Mexican States, supra note 52, art. 9(2) ("If extradition [of nationals of the requested State] is not granted ... the requested Party shall submit the case to its competent authorities for the purpose of prosecution, provided that Party has jurisdiction over the offense.") (emphasis added). 
be a crime in both countries, ${ }^{196}$ prevent extradition, provided that kidnapping is a crime in both the United States and the foreign state. The United States, by seeking out and prosecuting foreign government agents for violations of municipal law, thereby admits that immunity from extradition and prosecution in the United States is limited for foreign government agents. ${ }^{197}$

\section{IV}

\section{POLICY FAVORING EXTRADITION OF U.S. GOVERNMENT} AGENTS AND CONSTITUTIONAL LAW ISSUES

The discussion so far shows that, as a matter of both international and municipal law, foreign states may seek the extradition of U.S. government agents for cross-border abductions and that a U.S. court presented with the question could warrant such an extradition. However, even if extradition of government agents is the correct approach under law, the possibility that federal courts might warrant the extradition of U.S. government agents raises constitutional questions regarding separation of powers. These questions, however, can be resolved by examining the Executive and judiciary's respective constitutional and statutory roles in the extradition process.

\section{A. Policy Favoring Extradition of U.S. Government Agents}

Even though developments in international and municipal law indicate that federal courts could warrant the extradition of U.S. government agents who engage in cross-border abductions, the policy considerations involved might lead to a different decision. To justify legally a refusal to warrant extradition, courts could expand the application of extant exceptions to extradition and foreign prosecution or create a new one despite precedents like Collier. Thus, analysis of the countervailing legal policies involved must show that the legal ability to extradite is consistent with prudent legal practice.

First, ascertaining the exact status of the person whose extradition is requested may be extremely difficult, involving an examination of the merits of the case which, given the law governing the U.S. extradition process, would be more appropriate in the foreign venue. In every major U.S. case, whether the defendants were government agents was a potential question. Although the court in Kear v. Hilton treated the defendant as a private citizen, ${ }^{198}$ the difference between the quasi-public authority exercised by bondsmen or bounty hunters operating under a delegation of authority from a court and the public authority of government agents

196. See Factor v. Laubenheimcr, 290 U.S. 276, 290, 300 (1933); OPPENHEIM, supra note 82, pt. 3, $\S 419$; see also Act Charged, a Crime in Both Countries, 6 Whiteman DigeST $\S 13$.

197. See discussion supra Part III.A.2.

198. See supra text accompanying notes $36-40$. 
is not entirely clear. In any case, Kear and Johnsen could have reasonably claimed that they were authorized agents of the state of Florida, especially since Accredited's agreement with state authorities made it possible for Kear and Johnsen to receive a ten percent commission on the bond for bringing back Jaffe. ${ }^{199}$

Not even $\mathrm{Ker}$ is sacrosanct. A review of the briefs in $\mathrm{Ker}$ indicates that the detective, Julian, did not simply throw up his hands and abduct Ker once he arrived in Peru. At the time Julian arrived, Lima was controlled by the Chilean military while the Peruvian government was isolated eighty-five miles away. ${ }^{200}$ Over a period of several months, Julian made the acquaintance of Ker, and it was only after he sought and received the help of the Chilean military governor that he was able to place Ker on an American naval vessel. ${ }^{201}$ Thus, it is quite possible that Julian was acting well within the scope of his authority as a government agent, although the Supreme Court decided the case on the assumption that he was not.

In Alvarez-Machain, although Berrellez was clearly an agent of the U.S. government, the status of Gárate Bustamante and the Mexican citizens who carried out the abduction and who were later brought to the United States is unclear. Although the Supreme Court accepted the lower court's finding that the DEA was responsible for the abduction, ${ }^{202}$ there seems to be no difference between the abductors in AlvarezMachain and those in Villareal; in both cases, the abductors delivered a fugitive to a waiting law enforcement officer in return for a cash payment intended only for them..$^{203}$

In the United States, quite apart from the question of distinguishing between private citizens and government agents, there is also the problem of distinguishing between agents of the federal and state governments for the purpose of determining their extraditability. While presumably agents of U.S. states do not have authority to conduct operations in other countries given the federal government's primacy over foreign affairs, ${ }^{204}$ any distinction between federal and state agents would be

199. See Putnam County vs. Canada, supra note 31.

200. Charles Fairman, Ker v. Illinois Revisited, 47 AM. J. INT'L L. 678, $684-85$ (1953) (citing the state of Illinois' brief in Ker).

201. Id. at 685 .

202. United States v. Alvarez-Machain, 112 S. Ct. 2188, 2190 (1992).

203. See Villareal v. Hammond, 74 F.2d 503, 504 (5th Cir. 1934); Ex parte Lopez, 6 F. Supp. 342, 343 (S.D. Tex. 1934); supra text accompanying notes 153-56.

204. See U.S. CoNST. art. I, $\S 10$ (significantly limiting states' powers in foreign affairs); see also United States v. Pink, 315 U.S. 203, 226-34 (1942) (discussing federal government's, particularly Executive Branch's, primacy over state governments in foreign affairs); United States v. Belmont, 301 U.S. 324, 331 (1937) (same). The Supreme Court stated in Pink that "there are limitations on the sovereignty of the States. No State can rewrite our foreign policy to conform to its own domestic policies. Power over external affairs is not shared by the States; it is vested in the national government exclusively." Pink, 315 U.S. at 233. 
difficult to represent abroad and, in any case, would make no difference with respect to the unauthorized nature of the act under foreign municipal law. ${ }^{205}$

Furthermore, establishing an exemption for U.S. government agents raises the possibility that every case of extradition for cross-border abduction will be challenged on the basis of government authorization. An exemption would force courts to decide whether to impute responsibility to the U.S. government for an individual's violations of foreign law by exempting the individual from extradition, which would be questionable judicial practice given that the Executive's discretion in the field of foreign affairs is recognized and protected. ${ }^{206}$ A better practice would warrant extradition regardless of the assertion of U.S. government agent status and allow the Executive to decide the political question of whether it will accept responsibility for the acts of individuals by refusing to extradite them. ${ }^{207}$

Second, if the United States refused to extradite U.S. government agents without adequate legal justification, other countries might respond in kind by refusing to cooperate with the United States in matters of extradition or other aspects of international law. The dissent in AlvarezMachain, criticizing the majority's dismissal of the jurisdictional question, neatly summarized the issue by quoting Paine. Paine wrote, " $\mathrm{He}$ that would make his own liberty secure must guard even his enemy from oppression; for if he violates this duty he establishes a precedent that will reach to himself."208 In 1989, Legal Adviser Sofaer warned that the failure of the United States to extradite its agents could lead to reciprocal refusals by foreign countries to extradite fugitives to the United States. ${ }^{209}$ It is unknown whether the United States could make a convincing legal argument against extradition and trial of its agents; however, its past efforts to bring foreign government agents to trial in the United States indicate that it has already endorsed extradition as a legitimate course of action.

Third, the judiciary's interest in maintaining the integrity of the

205. Secretary of State Webster's utter inability to convince the British that he could not, in fact, order the release of Alexander McLeod from the New York State courts is instructive in this respect. See Letter from H.S. Fox, British Minister to Washington, to Secretary of State Daniel Webster, supra note 113 , at 1128 .

206. See infra notes 216-17 and accompanying text.

207. The Executive can use statutory discretion to refuse extradition. See infra notes 226-31 and accompanying text.

208. United States v. Alvarez-Machain, 112 S. Ct. 2188, 2206 (1992) (Stevens, J., dissenting) (quoting 2 The Complete Writings of Thomas Paine 588 (Philip S. Foner ed., 1945)).

209. See Sofaer, supra note 132, at 15-16; see supra text accompanying note 159 . In fact, the problem of reciprocity arose quickly after Alvarez-Machain when an extradition from Chile to the United States was almost blocked by the Chilean Supreme Court. The dissent in the case argued that Alvarez-Machain showed that the United States violates its extradition treaties. Kreczko, supra note 72 , at 7 . 
judicial system through exercise of its supervisory power indicates that courts should proceed with extradition if U.S. government agents have violated the laws of foreign states. The supervisory power is neither constitutional nor statutory but is rather a "judicial vehicle to deter conduct and correct injustices... which the court nonetlieless finds repugnant to fairness and justice and is loathe to tolerate."210 Supervisory power, while rather vaguely defined in relation to the judiciary's power to redress related violations of an individual's Fourth or Fifth Amendment rights, is more closely related to the sentiment expressed by Justice Brandeis in his oft-quoted dissent in Olmstead v. United States, in which he remarked that "[c]rime is contagious. If the Government becomes a lawbreaker, it breeds contempt for law."211

In cases of abduction and other irregular rendition, the supervisory power has been noted, but not used to any effect. ${ }^{212}$ Nevertheless, the same concern underlying the supervisory power of courts is present regardless of where such an abuse took place, whether in Beirut or Philadelphia. A violation of foreign laws by American law enforcement officers, especially those laws which are substantially similar to those within the United States and for which the United States would be likely to seek vindication if broken by foreign government agents, should trigger the same concerns about the integrity of the administration of justice. Thus, the court, by refusing to warrant extradition of U.S. government agents, would only reinforce an ambivalent attitude towards law enforcement by implicitly sanctioning the underlying cross-border abduction. ${ }^{213}$

Fourth, extradition of U.S. government agents should be the preferred method of resolving the dilemma, given that it uses the extant structure of international extradition, which has already been erected through a network of treaties between states. This kind of solution stands in marked contrast to the occasional, and usually vague, suggestion that the international extradition process be changed to deal with abuses. $^{214}$ Change is unnecessary if a sufficient remedy can be found in a

210. United States v. Noriega, 746 F. Supp. 1506, 1535 (S.D. Fla. 1990).

211. 277 U.S. 438, 485 (1928) (Brandeis, J., dissenting), overruled by Berger v. New York, 388 U.S. 41 (1967). Not surprisingly, Brandeis was also quoted by the dissent in Alvarez-Machain. 112 S. Ct. at 2205 n.33 (Stevens, J., dissenting).

212. This is largely due to the use of foreign police officers to make arrests, imparting no responsibility on the court to enforce the policy against abusive police procedure. See RESTATEMENT, supra note 86, § 433, reporter's notes 1-3. But see United States v. Lira, 515 F.2d 68, 73 (2d. Cir.) (Oakes, J., concurring) (maintaining that although jurisdiction was exercised over a defendant brought to the United States under questionable circumstances, the government was running the risk of forcing use of supervisory power), cert. denied, 423 U.S. 847 (1975).

213. See Evans, supra note 143, at 102-03 (noting that cross-border abductions result in an ambivalent attitude toward an important aspect of the administration of law).

214. See Bassiouni, supra note 10, at 238-39; Buser, supra note 24, at 376; Evans, supra note 143 , at $78-79$. 
system that is already im place and honored, if occasionally in the breach, by most nations.

\section{B. Separation of Powers and Justiciability}

Thus, serious policy pressures, having largely to do with the way international and municipal law work in reality, argue in favor of extraditing U.S. governnient agents who violate foreign municipal law. Regardless of legal policy, or of municipal or international law, lowever, the ability of a court to warrant extradition will hinge on the proper role of the federal courts in the constitutional structure. If extraditing U.S. government agents is thought to interfere directly witl the conduct of foreign affairs by the Executive, tlien federal courts would be obliged to refuse to pass on the question as a nonjusticiable political question. ${ }^{215}$

The extent of the Executive Brancli's power over foreign affairs lias been a topic of considerable debate; althougl not explicitly mandated by the Constitution, ${ }^{216}$ mucli of its power has been generally recognized by the Suprenie Court. ${ }^{217}$ Recognizing an obligation to stay clear of the Executive Brancli's power over foreign affairs, lowever, places tlie judiciary in a delicate situation when considering the extradition of U.S. governnent agents. The judiciary's power extends to all cases arising under treaties, ${ }^{218}$ including extradition treaties, which are considered to be selfexecuting and thus binding on all courts under the Supremacy Clause. ${ }^{219}$ Thus, regardless of the politics involved in a single case of extradition,

215. This is the reason for the act of state doctrine. See supra notes 71-72 and accompanying text; see also Banco Nacional de Cuba v. Sabbatino, 376 U.S. 398, 427-28 (1964) (noting that act of state doctrine's "continuing vitality depends on its capacity to reflect the proper distribution of functions between the judicial and political branches of the Government on matters bearing upon foreign affairs").

216. The rndiments of such a power may be found at U.S. CoNST. art. II, § 1, cl. 1 ("The executive Power shall be vested in a President of the United States of America."); see also United States v. Curtiss-Wright Export Corp., 299 U.S. 304, 320 (1936) (arguing that competence to deal with other nations passed to the federal government given the United States' status as a sovereign nation, and that the President is the "sole organ of the federal government in the field of international relations"). Regarding executive powers over the armed forces and in making treaties, see U.S. CoNST. art. II, § 2, cl. 1-2.

217. United States v. Pink, 315 U.S. 203, 229-30 (1942); Curtiss-Wright Export Corp., 299 U.S. at 320; see also Dames \& Moore v. Regan, 453 U.S. 654, 688 (1981) ("[W]here . . the settlement of claims [is] a necessary incident to the resolution of a major foreign policy dispute . . . and where ... we can conclude that Congress acquiesced in the President's action, we are not prepared to say that the President lacks the power to settle such claims."); Glennon, supra note 6, at 751 (noting powers of President when acting with congressional support); Halberstam, supra note 6, at 741 (noting Supreme Court's traditional deference to the Executive in matters of foreign affairs); $c f$. Monroe Leigh, Is the President Above Customary International Law?, 86 AM. J. INT'L L. 757 (1992) (arguing for limitations on presidential power).

218. "The judicial Power shall extend to all Cases, in Law and Equity, arising under this Constitution, the Laws of the United States, and Treaties made, or which shall be made, under their authority ... ."U.S. ConsT. art. III, $\S 2$, cl. 1 .

219. Terlinden v. Ames, 184 U.S. 270, 288 (1902); United States v. Rauscher, 119 U.S. 407, 418 19 (1886). 
the federal courts are under a constitutional duty to observe the law of the applicable extradition treaty.

A court, assuming it will resolve the legal problem in favor of extradition, must decide whether the question itself is justiciable. Regardless of the extent of the Executive's power over foreign affairs, it does not necessarily follow that every question touching on foreign affairs is nonjusticiable. ${ }^{220}$ The Supreme Court has subjected the Executive's actions in foreign countries to constitutional scrutiny. ${ }^{221}$ The application of the Fifth Amendment to the actions of U.S. government agents involved in arrests abroad in United States $v$. Toscanino and cases which have followed it is a patent, if somewhat controversial, example. ${ }^{222}$ In Baker $v$. Carr, the Court stated that foreign affairs questions can be subject to judicial review, with prior analyses focusing on the history of the management of the issue by the Executive, its susceptibility to judicial handling, and the possible consequences of judicial action. ${ }^{223}$

Following these indications of the justiciability of foreign affairs questions, extradition of U.S. government agents should be considered justiciable. Extraditions are legal proceedings. Courts handle extraditions daily with the initial review over cases explicitly granted to federal magistrate judges and district judges. ${ }^{224}$ Although Executive Branch power over foreign affairs has been recognized in the context of extraditions, it has usually been for the explicitly political questions associated with extradition, such as whether a treaty has been terminated, ${ }^{225}$ not the legal question of whether a court may warrant extradition.

Justiciability is also supported by the extradition process under the present federal statute. The statute mandates separation of the political side of extradition from its legal side; after a federal court has warranted extradition, the statute explicitly gives final discretion to the Executive to

220. "[I]t is error to suppose that every case or controversy which touches foreign relations lies beyond judicial cognizance." Baker v. Carr, 369 U.S. 186, 211 (1962).

221. See United States v. Verdugo-Urquidez, 494 U.S. 259 (1990) (discussing the merits of the case, although deciding the Fourth Amendment did not apply to foreign nationals in foreign countries); Reid v. Covert, 354 U.S. 1, 5-9 (1957) (applying constitutional standards to determine propriety of overseas military trial of U.S. civilians); see also Lowenfeld, supra note 45 , at 490 (urging reaffirmation of Reid).

222. United States v. Toscanino, 500 F.2d 267, 275 (2d Cir. 1974); see also United States ex rel. Lujan v. Gengler, 510 F.2d 62 (2d Cir.) (limiting Toscanino), cert. denied, 421 U.S. 1001 (1975); BASSIOUNI, supra note 10, at 201-04 (discussing Toscanino and subsequent cases).

223. Baker, 369 U.S. at 211-12. From this and other examples of how political questions have been handled, Justice Brennan derived several factors to be used in determining whether a case was justiciable. Id. at 217. For an examination of the Baker factors in another case involving foreign relations, see United States v. Noriega, 746 F. Supp. 1506, 1538-41 (S.D. Fla. 1990).

224. 18 U.S.C. $\S 3184$ (Supp. IV 1992). The role of courts in legal proceedings based on treaties of rendition was discussed as early as 1795 . In United States v. Lawrence, 3 U.S. (3 Dall.) 42 (1795), the Supreme Court refused to order a district court to change its decision under a convention between the United States and France providing for the rendition of naval deserters where the convention provided for a hearing and decision by a court. Id. at 52 .

225. Terlinden v. Ames, 184 U.S. 270, 285 (1902). 
order extradition by stating, "The Secretary of State may order the person [whose extradition has been warranted] to be delivered to any authorized agent of such foreign government, to be tried for the offense of which charged."226 Thus, although the law may require a court to warrant extradition, the Executive may elect not to issue an extradition order on the warrant since such an order is, like prosecution of crimes more generally, entrusted to the Executive's discretion. Although the limits to the Executive's ability to exercise this discretion are vague, they are recognized to be as broad as the Executive's interpretation of the treaty will allow, ${ }^{227}$ and several courts have already held that the exercise of Executive discretion is not open to further judicial review. ${ }^{228}$ This view cannot be literally true since it implies that even an unconstitutional abuse of discretion would not be subject to judicial review. Additionally, the idea of absolute, unreviewable discretion is somewhat suspect since it was taken not from Executive discretion over ordering extradition per se, but rather from the Supreme Court's affirmations of undoubted Executive discretion over political questions associated with extradition procedure. ${ }^{229}$ Regardless of its exact limits, however, Executive discretion is broad, may be exercised for political reasons, and is unlikely to be questioned by the courts. ${ }^{230}$ It was this Executive discretion upon which the Secretary of State relied after Collier v. Vaccaro to override what would have been a politically controversial order to extradite a U.S. government agent. ${ }^{231}$

The implications for the justiciability of extradition are obvious. If

226. 18 U.S.C. $\$ 3186$ (1988) (emphasis added). For discussions of $\S 3186$ and executive discretion in extradition, see In re United States, 713 F.2d 105, 108 (5th Cir. 1983); Escobedo v. United States, 623 F.2d 1098, 1105 (5th Cir. 1980), cert denied, 449 U.S. 1036 (1980), and cert. denied, 450 U.S. 922 (1981); Sindona v. Grant, 619 F.2d 167, 176 (2d Cir. 1980); Wacker v. Bisson, 348 F.2d 602, 606 (5th Cir. 1965); An Executive Function, 6 Whiteman Digest $§ 38$, at 1046. See generally Note, Executive Discretion in Extradition, 62 ColuM. L. REv. 1313 (1962). The first judicial recognition of Executive discretion under the statute occurred when the Secretary of State refused to extradite a fugitive to Prussia because he believed, contrary to the court which warranted extradition, that the crime was not cognizable under the treaty. In re Stupp, $23 \mathrm{~F}$. Cas. 281 (C.C.S.D.N.Y. 1873) (No. 13,562); 17 Op. Att'y Gen. 184, 185-87 (1881).

227. See Executive Discretion in Extradition, supra note 226, at 1316.

228. See Escobedo, 623 F.2d at 1105 ("[T]he Executive's discretionary determination to extradite . . . is not generally subject to judicial review.") (footnote omitted); Gallina v. Fraser, 177 F. Supp. 856, 867 (D. Conn. 1959) (holding that court may not presume that Secretary of State will permit extradition "contrary to well known principles of fairness" and that decisions regarding extradition fall "peculiarly within the province of the State Department"), aff'd, 278 F.2d 77 (2d Cir.), cert. denied, 364 U.S. 851 (1960); cf. Chicago \& S. Air Lines, Inc. v. Waterman S.S. Corp., 333 U.S. 103, 111-14 (1948) (courts cannot review President's exercise of congressionally delegated discretion over applications for authority to engage in overseas air transportation).

229. Terlinden v. Ames, 184 U.S. 270, 288-90 (1902).

230. See RESTATEMENT, supra note $86, \S \S 475 \mathrm{cmt}$. g, $478 \mathrm{cmt}$. d.

231. 51 F.2d 17, 20-21 (4th Cir. 1931) ("Notwithstanding the discharge of the writ, the Secretary of State may review the evidence before the magistrate and decide whether the case presented is one calling for the surrender of the accused to the authorities of the foreign country."); see also Weight and Effect of Evidence, supra note 143, at 162-63 (discussing Collier); Executive 
statutory law mandates that the Executive Branch is the only forum of appeal for any decision by a federal court to warrant the extradition of a U.S. government agent, then there is no danger of the court overstepping its bounds. The judiciary's determination can be reversed by the Executive, which is not normally the case in a nonjusticiable foreign affairs question. ${ }^{232}$ This power was freely admitted by the court, and exercised by the Secretary of State, in Collier. ${ }^{233}$

If a court held the question to be nonjusticiable, despite the statutorily mandated extradition procedure, it may in fact be usurping power from the Executive. If the exercise of Executive discretion over extradition does not arise until after it has been warranted, a court refusing to hear the case because of its political nature would, in effect, substitute the court's appreciation of the political aspects of a given case for the Secretary of State's. The Executive Branch would never have the opportunity to determine whether political considerations require that extradition be denied. In short, if the Executive Branch deems it politically expedient, or even legally justified (assuming its interpretation of applicable law differs from that of the court), not to extradite U.S. government agents, then that determination should be, and has been, left to the Executive Branch.

\section{CONCLUSION}

We have yet to see the prosecution of the abductors involved in Alvarez-Machain, nor does this Comment argue that their extradition should necessarily take place. Under the analysis of this Comment, however, a U.S. court should warrant extradition of the Mexican citizens who performed the abduction despite their possible status as U.S. government agents. Similarly, Gárate Bustamante should probably also be held extraditable. ${ }^{234}$ Berrellez apparently remained in the United States dur-

Discretion in Extradition, supra note 226, at 1320 \& n.55 (same); supra notes $148-50$ and accompanying text.

232. The Executive's power to reverse the judiciary's determination of extraditability does not give rise to a constitutional question of finality. First mentioned in Hayburn's Case, 2 U.S. (2 Dall.) 409 (1792), the doctrine of finality derives from Article III of the Constitution, and prevents federal judges from acting in nonjudicial capacities, as they would if their holdings on a matter could be reversed by the Executive. Thus it prevents judges form acting as mere administrative functionaries. When a federal judge warrants extradition, however, she eertainly acts in a judicial capacity, see supra note 224, similar to her capacity to issue search warrants. Cf. Tutun v. United States, 270 U.S. 568, 578 (1926) (holding that federal courts passing on applications for citizenship fell within their powers under Article III, and stating, "[i]n passing upon the application the court exereises judicial judgment. It does not confer or withhold a favor."). Thus, the Executive only excrcises its discretion to avoid acting on the warrant. See supra notes 226, 228.

233. 51 F.2d at 20. The court's explicit reliance on the Executive's discretion supports the point that the statutory extradition procedure does not violate the constitutional doctrine of finality. See supra note 232 .

234. It is unclear from the facts of the case whether Gárate Bustamante personally made arrangements in Mexico, although from the recounting by the lower court it seems that he did. See 
ing the abduction and is in a much more problematic situation, since he would be properly authorized under territorial law to engage in law enforcement activities. ${ }^{235}$ If a court decided to extradite any of them, the Executive Branch would be presented with the opportunity to resolve at least one of the legal consequences of the cross-border abduction it authorized.

Warranting extradition for U.S. government agents will not solve the problems, both legal and pohtical, associated with cross-border abductions. The violation of foreign mumicipal law, however, is a legal consequence of cross-border abductions that cannot be ignored; it exists and extradition may be insisted upon by an offended foreign state. Should the other branches of government decide that this interpretation of extradition law oversteps the bounds of the judiciary, then they may, no doubt, change the law of extradition by modifying extant extradition statutes. ${ }^{236}$ It is hoped that as a result of the diplomatic and legal furor over Alvarez-Machain, the incidence of cross-border abductions will not be such as to require legislative action. ${ }^{237}$

If, however, cross-border abductions lead to more requests for the extradition of U.S. government agents, whatever resolution becomes part of American law must be a legal resolution. With this in mind, warranting extradition of U.S. government agents is not an intrusion by the courts into the protected sphere of the Executive Branch's power over foreign affairs but is rather an example of courts avoiding involvement in political affairs. Courts would only be doing what they are supposed to

United States v. Caro-Quintero, 745 F. Supp. 599, 603 (C.D. Cal. 1990), aff'd sub nom. United States v. Alvarez-Machain, 946 F.2d 1466 (9th Cir. 1991), rev'd, 112 S. Ct. 2188 (1992).

235. Berrellez' case also raises questions as to whether extradition can be sought for people who do not enter a territory but nevertheless cause effects within that territory. Prevailing U.S. law would not bar extradition in such a case. See Melia v. United States, 667 F.2d 300, 302 (2d Cir. 1981) (granting extradition of a defendant to Canada for conspiring to murder through telephone calls from the United States); RESTATEMENT, supra note 86, § 475 reporter's note l; Jurisdiction, 6 Whiteman Digest $\$ 20$, at 900-04; see also OPPENHEIM, supra note 82, pt. 1, $\$ 139$ (discussing jurisdiction based on effects within a territory); cf. Strassheim v. Daily, 221 U.S. 280, 284-85 (1911) (Holmes, J.) (allowing extradition of defendant to Michigan even though fraud directed from outside state).

236. Congressional action in the field of international rendition is not unknown, and has the potential to radically alter Executive practice. For example, as a response to Alvarez-Machain, Congressman Panetta introduced a bill in July 1992 which would have prohibited prosecution of people abducted by U.S. government agents abroad. H.R. 5565, 102d Cong., 2d Sess. (1992); see also 138 CoNG. Rec. H6019 (daily ed. July 7, 1992) (statement of Rep. Panetta). However, the bill failed.

237. This, however, remains to be seen. In October 1992, a Cypriot national was arrested by customs agents who lured him onto a plane in the Bahamas, eliciting a protest by the Bahamian government. The case is still pending, and has not yet been resolved by the new administration. Michael Isikoff, U.S. Customs "Sting" Nets Cypriot, Angers Bahamas, WASH. Post, Feb. 5, 1993, at A2. Even more recently, the questionable expulsion of Mahmud Abouhalima from Egypt during the investigation into the March 1993 bombing of the World Trade Center also raises questions as to whether the new administration will change U.S. policy. See Susan Sachs \& Kevin McCoy, Suspect's Transfer Worries Egyptians, NEwSDAY, Mar. 25, 1993, at 32. 
do: applying the law to the facts in front of them and leaving the political questions of denying extradition to the Branch where such a decision properly belongs. Such a distribution of responsibility not only makes sense given the traditional distribution of power within the American system but provides a model for resolving other questions touching on foreign affairs. As Alvarez-Machain revealed, where foreign affairs is concerned, the Judicial Branch is only too prone to abdicate its constitutional duties. 